\title{
Some Clarity On Mutual Fund Fees
}

\author{
Stewart Brown ${ }^{1}$ \\ Steven Pomerantz
}

\begin{abstract}
Analyses of mutual fund fees have differed over whether fees are responsive to the forces of competition. Some academic and legal scholars argue that because mutual fund markets possess some of the indicia of competitive markets, fees must approximate marginal costs and thus cannot be excessive. Others argue that structural anomalies in mutual fund governance allow fund managers to overcharge mutual fund investors. This Paper resolves the disagreement. It presents compelling evidence that investment management fees, a major component of total fees are immune to the forces of competition. This is accomplished with a combination of financial and legal analysis.

We survey the universe of mutual fund assets and fees over time. We find that between 2005 and 2015 total expense ratios declined; principally because investors allocated an increased proportion of their funds to passively managed open-end and exchange traded funds. However, over the same period assets on actively managed open-end funds more than doubled while investment management fees, also known as advisory fees increased slightly. This outcome is inexplicable in economic terms but consistent with the legal environment the investment management industry operates in. Indeed, we show how the industry has shaped the environment.

The genesis of the fee anomaly is the 1970 Amendment to the Investment Company Act of 1940. Studies by the Wharton School and the SEC showed investment management fees higher than fees subject to competitive forces. The Commission recommended that advisory fees
\end{abstract}

1. Stewart Brown is Emeritus Professor of Finance at Florida State University. B.S.B.A., 1970; M.B.A., 1971; Ph.D., 1974, University of Florida.

Steven Pomerantz is a financial consultant. B.A., 1981, Queens College, City University of New York; Ph.D., 1986, University of California-Berkeley.

The authors are grateful to Steven Celec, Mary McCormick and David Rasmussen for comments on earlier drafts of the Paper.. 
should be "reasonable" and enforceable in court. The investment management industry pushed back against this recommendation and successfully killed the Commission's proposal, following which Congress, the Commission, and the industry crafted a "compromise" that made investment advisers fiduciaries with respect to fees and gave investors a private cause of action.

As evidenced by the inelasticity of management fees, the purported solution to the problem was ineffective. We show how Congress signaled its endorsement of the status quo and how the courts have interpreted the Congressional signal: cases up to and including the recent Supreme Court decision in Jones $v$. Harris have been uniformly negative for plaintiffs. No plaintiff has ever received an award under the 36(b) statute.

As a result of the industry-favoring political and judicial environment, investors in actively managed mutual funds are overcharged by about $\$ 30$ billion per year. The investment management firms who sponsor and brand actively managed mutual funds earn monopoly profits and excess returns for their owners.

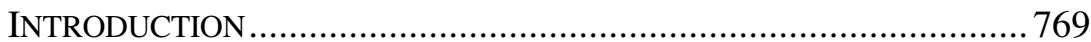

I.TRENDS IN MUTUAL FUND ASSETS AND FEES..............................771

A. The Universe of Mutual Funds 2005 to 2015 ..................771

B. Analysis of Fees on the Universe of Actively Managed Open-end Funds.

II.LEGAL AND REGULATORY UNDERPINNINGS OF MUTUAL FUND

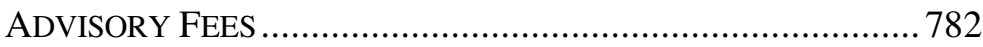

A. The Judiciary Weighs In ...............................................788

B. Updating the Wharton Study and PPI Report..................795

C. The Industry Response .................................................... 797

D. The U.S. Supreme Court Weighs in: Jones v. Harris

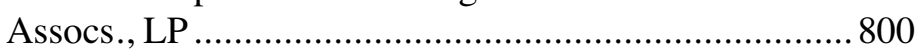

E. Sub-Advisory Fee Cases .................................................. 801

III.THE ECONOMIC CONSEQUENCES OF EXCESSIVE ADVISORY FEES

A. Estimating Annual Excess Advisory Fees......................802

B. Excess Returns to Fund Sponsors ..................................... 808

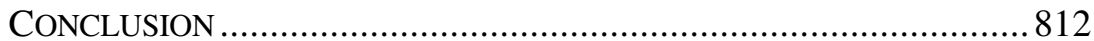




\section{INTRODUCTION}

The financial services sector grew from $4.9 \%$ to $8.3 \%$ of GDP between 1980 and 2006. ${ }^{2}$ Malkiel attributes a large proportion of this growth to increases in the fees paid for asset management. ${ }^{3}$ He notes that "perhaps the greatest inefficiency in the stock market is in 'the market' for investment advice .... [T] he scale economies in asset management appear to have been entirely captured by the asset managers. ${ }^{\prime 4}$

Mutual fund fees are a primary cause of the well-documented underperformance of actively managed funds versus index funds. ${ }^{5}$ Carhart found that persistent differences in mutual fund expenses and transaction costs explain almost all of the predictability of mutual fund returns. ${ }^{6}$ A recent study published by Morningstar updated and confirmed these results. ${ }^{7}$

On the surface, the mutual fund industry seems to correspond closely to the model of perfect competition: a large number of buyers and sellers, no significant barriers to entry or exit, perfect information, and a homogeneous product. Traditional economic analysis argues that competitively determined prices will equal marginal costs and thus cannot be excessive.

However, there is substantial disagreement about mutual fund fees in the literature. While some scholars argue that there is a lack of price competition among funds, ${ }^{8}$ other's present evidence that the mutual fund industry behaves competitively. ${ }^{9}$ The academic literature largely ignores the

2. Burton G. Malkiel, Asset Management Fees and the Growth of Finance, 27 J. Econ. PERSP. 2 (Spring 2013), at 97.

3. Id.

4. Id. at 98-99.

5. See Mark M. Carhart, On Persistence in Mutual Fund Performance, 52 J. Fin. 57, 80 (1997) (finding that load fees, expense ratios, and portfolio turnover are significantly and negatively related to performance).

6. Id. at 57 .

7. Russel Kinnel, Predictive Power of Fees: Why Mutual Fund Fees are so Important, MorNingstar MANAGER Res. May 2016, http://corporate1.morningstar.com/ResearchArticle.aspx?documentId=752589 (finding that the cheapest quintile funds were three times as likely to succeed as the priciest quintile).

8. See e.g., John A. Haslem et al., Are Retail $S \& P 500$ Index Funds a Financial Commodity? Insights for Investors, 15 FIN. SERV. REV. 99 (2006) (concluding there is a lack of price competition after finding a high level of dispersion in expense ratios across retail S\&P 500 Index funds); Javier Gil-Bazo \& Pablo Ruiz-Verdú, The Relation Between Price and Performance in the Mutual Fund Industry, 64 J. FIN. 2153 (2009) (discovering that funds with worse before-fee performance charge higher fees); Laurent Barras et al., False Discoveries in Mutual Fund Performance: Measuring Luck in Estimated Alphas, 65 J. Fin. 179 (2010) (finding that seventy-five percent of funds showed no positive return net of fees).

9. See e.g., Ajay Khorana et al., Mutual Fund Fees Around the World, 22 Rev. Fin. STUD. 1279 (2009) (finding that differences in fees can be explained by a combination of investment objective, size of fund, geographic distribution of fund, and degree of government investor protection); Sunil Wahal \& Albert Wang, Competition Among Mutual Funds, $99 \mathrm{~J}$. 
legal and regulatory milieu in which mutual funds and mutual fund managers operate. An examination of the legal issues yields important insights into the impact of the legal and regulatory environment on mutual fund "markets."

The purpose of this Paper is to explore mutual fund fees in depth. It resolves the disagreement about competition in mutual fund "markets" by demonstrating that an important component of fund fees is immune to the forces of competition. It accomplishes this with a combination of economic and legal analysis.

In Part I, we study asset and fee levels of the universe of mutual funds between 2005 and 2015. Using the Morningstar Direct database, we examine changes in assets and asset-weighted expenses of funds disaggregated by open-end, closed-end, exchange traded (ETF), active, passive and money market. More importantly, we disaggregate the Total Expense Ratio (TER) on actively managed open-end funds and find strong evidence that management (advisory) fees, a component of the TER, are immune to the forces of competition. We trace this immunity to the 1970 amendments ${ }^{10}$ to the Investment Company $\mathrm{Act}^{11}$ and analyze the cases that have interpreted it.

Part II explores the legal and regulatory underpinnings of advisory fees and sorts out the factors that mitigate against competitive forces. Unlike most corporations, mutual funds have no employees or physical assets. Instead, mutual funds are essentially a collection of contracts with services providers, the most important of which is the investment management firm ${ }^{12}$ that creates, brands and manages the fund's portfolio. ${ }^{13}$ These differences have caused the U.S. Supreme Court to recognize that "the forces of arm'slength bargaining do not work in the mutual fund industry in the same manner as they do in other sectors of the American economy." $" 14$

In Part III we examine the economic consequences of the legal environment. Previous research has shown that mutual fund advisory fees

FIN. ECON. 40 (2011) (concluding the mutual fund industry is competitive after finding that incumbent funds that have high investment overlap with new entrants, subsequently engage in price competition by reducing management fees); Martijn Cremers et al., Indexing and Active Fund Management: International Evidence, 120 J. FIN. ECON. 539 (2016) (finding that the availability of indexed funds is associated with improved competition).

10. 15 U.S.C. § 80a-35b (2006).

11. Investment Company and Investment Advisers Act of 1940, 54 Stat. 789 (1940) (codified as amended at 15 U.S.C. $\S \S 80 a-1$ to 80a-64 (2012).

12. Investment managers who create and manage mutual funds are also referred to as fund sponsors.

13. See Stewart L. Brown, Mutual Funds and the Regulatory Capture of the SEC, $19 \mathrm{U}$. PA. J. Bus. L. 701, 713 (2017) (hereinafter "Regulatory Capture") (describing how mutual funds work).

14. Jones v. Harris, 559 U.S. 335, 338 (2009). 
are substantially higher than comparable institutional advisory and mutual fund sub-advisory fees, both of which are heavily influenced by competitive forces. ${ }^{15}$ This Paper finds similar results and concludes that the investing public is overcharged by about $\$ 30$ billion annually in excess advisory fees. In addition, because fund sponsors charge above market advisory fee rates, they earn economic profits for their owners. We determine that the universe of publicly traded mutual fund sponsors has earned very high and statistically significant excess returns for owners over long time periods.

Finally, in Part IV we present a summary and conclusions.

\section{TRENDS IN MUTUAL FUND ASSETS AND FEES}

\section{A. The Universe of Mutual Funds 2005 to 2015}

The universe of domestic mutual funds includes all open-end, closedend, and exchange traded funds. In Table 1, we compare asset levels and asset-weighted expense ratios for the ten-year period spanning 2005 to 2015, using data from the Morningstar Direct database.

15. See John P. Freeman \& Stewart L. Brown, Mutual Fund Advisory Fees: The Cost of Conflicts of Interest, 26 J. CORP. L. 609, 635 (2001) (hereinafter "Freeman-Brown") (comparing the advisory fees for mutual funds and public pension funds); see also H. Norman Knickle, The Mutual Fund's Section 15(c) Process: Jones v. Harris, the SEC and Fiduciary Duties of Directors, 31 Rev. BANKING \& Fin. L. 265, $294-95$ (2011) (sharing findings that mutual fund fees are higher than fees charged by pension plans and other institutional clients). 


\begin{tabular}{|c|c|c|c|c|}
\hline \multicolumn{5}{|c|}{$\begin{array}{ll}\text { Table } 1 & \end{array}$} \\
\hline \multirow{2}{*}{\multicolumn{5}{|c|}{$\begin{array}{c}\text { The Universe of Mutual Funds - Assets and Asset Weighted Expenses - } 2005 \text { to } 2015 \\
\text { Percent }\end{array}$}} \\
\hline & & & & \\
\hline & 2005 & 2015 & Change & Change \\
\hline \multicolumn{5}{|l|}{ (A) Universe of Mutual Funds } \\
\hline Assets & $\$ 6.79$ Trillion & \$16.43 Trillion & $142 \%$ & $\$ 9.61$ Trillion \\
\hline Total Expense Ratio & 0.769 & 0.547 & $-28.9 \%$ & $(0.222)$ \\
\hline Number of Funds & 5530 & 8876 & $60.5 \%$ & 3346 \\
\hline \multicolumn{5}{|l|}{ (B) Exchange Traded Funds } \\
\hline Assets & \$303 Billion & \$2.17 Trillion & $606 \%$ & $\$ 1.84$ Trillion \\
\hline Total Expense Ratio & 0.267 & 0.246 & $-7.9 \%$ & $(0.021)$ \\
\hline Number of Funds & 206 & 1849 & $798 \%$ & 1643 \\
\hline \multicolumn{5}{|l|}{ (C) Closed-End Funds } \\
\hline Assets & \$151 Billion & \$209 Billion & $38.7 \%$ & $\$ 58$ Billion \\
\hline Total Expense Ratio & 1.19 & 1.25 & $5.0 \%$ & 0.06 \\
\hline Number of Funds & 362 & 508 & $40.3 \%$ & 146 \\
\hline \multicolumn{5}{|l|}{ (D) Universe of Open-End Funds } \\
\hline Assets & $\$ 6.34$ Trillion & \$14.05 Trillion & $122 \%$ & $\$ 7.71$ Trillion \\
\hline Total Expense Ratio & 0.783 & 0.582 & $-25.7 \%$ & -0.201 \\
\hline Number of Funds & 4962 & 6519 & $31.4 \%$ & 1557 \\
\hline \multicolumn{5}{|l|}{ (E) Passively Managed Open-End Funds } \\
\hline Assets & \$545 Billion & \$2.01 Trillion & $268 \%$ & $\$ 1.47$ Trillion \\
\hline Assets $-\%$ of Open End & $8.6 \%$ & $14.3 \%$ & $66.2 \%$ & $5.7 \%$ \\
\hline Total Expense Ratio & 0.268 & 0.131 & $-51.0 \%$ & $(0.136)$ \\
\hline Number of Funds & 319 & 454 & $42.3 \%$ & 135 \\
\hline \multicolumn{5}{|l|}{ (F) Money Market Funds } \\
\hline Assets & \$1.19 Trillion & \$2.53 Trillion & $113 \%$ & \$1.34 Trillion \\
\hline Total Expense Ratio & 0.378 & 0.130 & $-66 \%$ & $(0.247)$ \\
\hline Number of Funds & 328 & 391 & $19.2 \%$ & 63 \\
\hline \multicolumn{5}{|c|}{ (G) Actively Managed (non Money Market) Open-End Funds } \\
\hline Assets & \$4.6 Trillion & S9.51 Trillion & $107 \%$ & \$4.90 Trillion \\
\hline
\end{tabular}

Line A of Table 1 reveals that mutual fund assets increased by $142 \%$ between 2005 and 2015, from about $\$ 6.8$ trillion to $\$ 16.4$ trillion. Over the same period, weighted average expense ratios fell from seventy-seven basis points to fifty-five basis points, a decrease of twenty-two basis points and a percentage decrease of $29 \%$. There was a $\$ 9.6$ trillion increase in mutual fund assets caused by a combination of increased asset values of the underlying securities and new funds flowing into mutual funds.

Line B shows that a substantial part (about $\$ 1.8$ trillion) of the increase in fund assets came from an explosion of Exchange Traded Fund (ETF) assets that increased more than $600 \%$, from about $\$ 300$ billion to $\$ 2.1$ trillion. At the same time, the number of ETFs offered in the market increased by about $800 \%$ so that the average ETF decreased in size from about $\$ 1.9$ billion in assets to about $\$ 1.4$ billion. Weighted average fees (expense ratios) on ETFs decreased slightly from twenty-seven to twentyfive basis points. In 2005, when the movement was in its infancy, the bulk of ETFs were plain vanilla index funds such as the State Street S\&P 500 ETF, which in 2005 had assets of $\$ 59$ billion and an expense ratio of 10 basis 
points. By 2015 , the fund had grown to $\$ 182$ billion and the expense ratio had fallen to nine basis points. Over the same time period, the Vanguard Total Stock ETF grew from $\$ 5.6$ to $\$ 57$ billion and the expense ratio fell from seven to five basis points. ${ }^{16}$

After 2005, the industry offered an array of increasingly complex ETFs such as international, smart beta, leveraged and derivative based products. These tend to have higher expense ratios. For instance, the most expensive domestic ETF in 2015 was the Teucrium Corn fund with an expense ratio of 403 basis points and $\$ 61$ million of assets under management. The fund did not exist in 2005. Similarly, a Proshares VIX Short Term Futures ETF had $\$ 633$ million in assets and an expense ratio of 1.4. The fund allows investors to speculate on market volatility. Hundreds of new ETFs were created to mimic Chinese and other international equities.

Morningstar categorizes \$2.14 of the \$2.17 trillion of ETFs as of 2015 as "passive" or passively managed. However, this is somewhat misleading. Although technically ETFs are passively managed, they constitute the majority of trading volume on the New York Stock Exchange and thus a principal use is in short term trading. Some investors clearly use ETFs for long term passive investing but there is ambiguity as to what proportion of ETFs are utilized in this fashion.

Line $\mathrm{C}$ of Table 1 shows that closed-end fund assets increased by about $39 \%$ from $\$ 151$ billion to $\$ 209$ billion. The average expense ratio increased slightly, and the average closed-end fund decreased slightly in size because the number of closed-end funds offered increased by about $40 \%$.

Line D of Table 1 strips out ETFs and closed-end funds from the universe of funds, leaving the universe of open-end funds, including money market funds and actively and passively managed funds. The universe of open-end funds grew from about $\$ 6.3$ trillion in assets in 2005 to about $\$ 14.1$ trillion in 2015, an increase of $122 \%$. The asset-weighted Total Expense Ratio fell by twenty basis points from 78 to fifty-eight basis points.

Much of the decrease in expense ratios for open-end funds occurred because investors switched from actively to passively managed funds as illustrated in Line $\mathrm{E}$ of Table 1. Open-end index fund assets increased from about $\$ 545$ billion to $\$ 2$ trillion between 2005 and 2015, an increase of $268 \%$, while the weighted average index fund expense ratio fell more than $50 \%$ from twenty-seven to thirteen basis points. Open-end index fund assets increased from $8.6 \%$ to $14.3 \%$ of all open-end funds.

The dramatic decrease in interest rates between 2005 and 2015 also contributed to the overall fall in expense ratios on open-end funds. Line F shows that money fund assets more than doubled over the period while

16. Vanguard is a mutual fund organization and provides its funds at cost to investors. 
money fund expense ratios fell $66 \%$ from thirty-eight to thirteen basis points. Given a near zero interest rate environment in 2015, money fund managers were forced to dramatically increase fee waivers to avoid imposing a negative rate of return on money funds.

Excluding index and money market funds from the universe of openend funds leaves the universe of actively managed, non-money market funds in Line $\mathrm{G}$ of Table 1. Actively managed fund assets doubled from about $\$ 4.6$ trillion to $\$ 9.5$ trillion, but the share of actively managed funds fell from 73 to $68 \%$ of the total of all open-end funds. Weighted average expense ratios fell from 95 to 80 basis points, a 16\% decrease and about half of the overall decrease in expense ratio of the universe.

In summary, from 2005 to 2015 mutual fund assets increased dramatically with a disproportionate increase in ETFs and index funds. There was a concomitant and expected decrease in overall expense ratios, but smaller expense decreases on actively managed funds. We examine the universe of actively managed funds in the next section.

\section{B. Analysis of Fees on the Universe of Actively Managed Open-end Funds}

The Total Expense Ratio consists of the sum of three broad components: administrative fees, distribution fees and management fees. Administrative fees are the sum of fees paid to various service providers of the fund including directors, the Transfer Agent (TA), the custodian and the fund accountant. Distribution fees are fees, also known as 12b-1 fees, after an SEC rule passed in 1980, charged against fund assets that cover fund marketing costs. ${ }^{17}$ Management fees ${ }^{18}$ are percentage fees charged against average assets and paid to the manager of the fund's portfolio.

Panel A of Table 2 presents a breakdown of these three broad categories for the universe of actively managed open-end funds for the 2005 to 2015 period. It reveals that the decrease in the weighted average total expense ratio was the result of decreases in administrative and distribution fees. Advisory fees, however, were flat over the period in spite of a doubling of assets. We will consider this important finding after discussing

17. See Bearing of Distribution Expenses by Mutual Funds, 45 Fed. Reg. 73, 898 (Nov. 7, 1980) (codified at 17 C.F.R. pt. 270.12b-1).

18. Management fees are sometimes called portfolio management fees or advisory fees. Because the term "management fees" could be confused with administrative fees, in this Paper we consistently label portfolio management fees as simply "advisory" fees. 
administrative and distribution fees.

Table 2

Analysis of Fees on Actively Managed Open End Funds

\begin{tabular}{|c|c|c|c|c|}
\hline \multicolumn{5}{|c|}{ Analysis of Fees on Actively Managed Open End Funds } \\
\hline & & \multicolumn{3}{|c|}{ Percent } \\
\hline Panel A & 200 & \multicolumn{2}{|c|}{2015 Change } & \multirow[t]{2}{*}{ Change } \\
\hline Expense Detail - Actively Managed (non & ket) Open End F & & & \\
\hline Assets & \$4.6 Trillion & 9.51 Trillion & $106.5 \%$ & $+\$ 4.9$ Trillion \\
\hline Weighted Average Total Expense Ratio & 0.949 & 0.797 & $-16.0 \%$ & $(0.152)$ \\
\hline Weighted Average Administrative Fees & 0.206 & 0.149 & $-27.7 \%$ & $(0.057)$ \\
\hline Weighted Average Distribution Fees & 0.212 & 0.117 & $-44.8 \%$ & $(0.095)$ \\
\hline Weighted Average Advisory Fees & 0.530 & 0.532 & $0.4 \%$ & 0.002 \\
\hline
\end{tabular}

Panel B

Analysis of Distribution Fees

Actively Managed Assets

Active Assets with $12 \mathrm{~b}-1$ Fees

$12 \mathrm{~b}-1$ Assets as a \% of Total

Detail of Distribution Fees

Shareholder Service Fees (12b-1 Fees $<=25$ BP)

CDSC Fees (12b-1 fees > 25 BP)

Total Active 12b-1 Fees

Panel C

Detail of Advisory Fees

Assets

Weighted Average Advisory Fees

Median Advisory Fee

Number of Actively Managed Funds

Average Fund Size

Number of Fund Sponsors

$\begin{array}{cccc}\text { \$4.6 Trillion } & 9.51 \text { Trillion } & 106.5 \% & +\$ 4.9 \text { Trillion } \\ \text { \$2.6 Trillion } & \$ 3.8 \text { Trillion } & 45.8 \% & +\$ 1.2 \text { Trillion } \\ 56.4 \% & 39.8 \% & -29.4 \% & -16.6 \% \\ & & & \\ & & & \\ \$ 3.1 \text { Billion } & \$ 5.6 \text { Billion } & 82.6 \% & \$ 2.5 \text { Billion } \\ \text { \$6.7 Billion } & \$ 5.5 \text { Billion } & -18.4 \% & (\$ 1.2 \text { Billion }) \\ \$ 9.8 \text { Billion } & \$ 11.1 \text { Billion } & 13.4 \% & \$ 1.3 \text { Billion }\end{array}$

$\begin{array}{cccc}\text { \$4.6 Trillion } & 9.51 \text { Trillion } & 106.5 \% & +\$ 4.9 \text { Trillion } \\ 0.530 & 0.532 & 0.4 \% & 0.002 \\ 0.77 & 0.84 & 9 \% & 0.07 \\ & & & \\ 4315 & 5674 & 31 \% & 1359 \\ \$ 1.07 \text { Billion } & \$ 1.68 \text { Billion } & 57 \% & \\ 507 & 737 & 45 \% & 230\end{array}$

Administrative Fees. The decrease in administrative fees is not surprising. Administrative services are likely to be subject to economies of scale and there is robust and transparent competition to provide most of these services. The TA contract is the most consequential of the administrative contracts. The TA is the entity that keeps the books on fund shareholders. It tallies purchases and sales and distributes dividends and reports, etc. The TA and various service/sales personnel who are compensated via distribution fees are the interface with fund shareholders. Collectively, they insulate the portfolio manager from all interactions with shareholders. TAs are often subsidiaries of the large fund families. The smaller fund sponsors contract with third party providers, often large banks that also provide the bulk of custodial services for fund portfolios. 
Distribution Fees. Distribution fees are an often-misunderstood portion of expense ratios. As originally designed by the SEC, distribution fees were marketing fees charged against the assets of existing customers to attract new customers. Marketing fees are a normal expense of the investment management company that sponsors the fund and would typically be charged against the management company's profits. However, in what Brown has characterized as a regulatory capture "coup,"19 the investment management industry convinced the SEC to allow fund management to tap fund assets via SEC Rule 12b-1.

The industry initially argued that such fees would eventually lead to a reduction in overall fees because of economies of scale in the advisory function. ${ }^{20}$ The anticipated savings never materialized. ${ }^{21}$ Fund sponsors continue to charge distribution fees, but the fees have been transformed into uses not originally intended by the SEC, i.e., to support sales commissions. As originally implemented, the rule allowed fund management to tap assets up to twenty-five basis points per year. ${ }^{22}$ This ceiling on what are currently referred to as "shareholder service" fees, remains in effect today. Funds with such shareholder service fees may characterize themselves as "no-load" funds. ${ }^{23}$

Distribution fees on funds that charge some form of sales load are currently capped at 100 basis points. The incremental seventy-five basis points support Contingent Deferred Sales Charges (CDSCs), a means of paying sales loads over times by incremental increases in expense ratios via $12 \mathrm{~b}-1$ fees. ${ }^{24}$ CDSCs sometimes camouflage sales loads and some investors are unaware that the fund salesperson is earning a commission. ${ }^{25}$

19. Regulatory Capture, supra note 13, at 716.

20. See John Freeman, The Mutual Fund Distribution Fee Mess, 32 J. CorP. L. 739, 768 (2007) (explaining that these theorists believed that money could be taken from mutual fund shareholders to pay for the marketing efforts in a way that would yield savings as the fund grew).

21. Div. of Inv. Mgmt., U.S. Sec. \& Exch. Comm'n, Report on Mutual Fund Fees AND EXPENSES III (D) (2)(2000), http://www.sec.gov/news/studies/feestudy.htm; LORI Walsh, The Costs and Benefits to Fund Shareholders of 12B-1 Plans: AN EXAMINATIONS OF Fund Flows, EXPENSES AND RETURNS (2004), https://www.sec.gov/rules/proposed/s70904/lwalsh042604.pdf.

22. See FINRA Rule 2341(d)(4) ("No member or person associated with a member shall, either orally or in writing, describe an investment company as being "no load" or as having "no sales charge" if the investment company has a front-end or deferred sales charge or whose total charges against net assets to provide for sales related expenses and/or service fees exceed .25 of $1 \%$ of average net assets per annum.").

23. Fast Answers: Mutual Fund Fees and Expenses, U.S. Sec. \& ExсH. Comm'N, https://www.sec.gov/fast-answers/answersmffeeshtm.html\#distribution (last visited Oct. 16, 2017).

24. FINRA Rule 2341(d)(2).

25. John Freeman, supra note 20, at 761. 
Panel B of Table 2 shows that between 2005 and 2015 actively managed assets carrying some form of distribution fees increased by about $46 \%$ from $\$ 2.6$ to $\$ 3.8$ trillion. The increase was at a lower rate than overall active assets so that the proportion of actively managed assets carrying distribution fees fell from about $56 \%$ to $40 \%$.

Shareholder service fees increased $83 \%$, from $\$ 3.1$ billion to $\$ 5.6$ billion. At the same time total CDSC fees fell $18 \%$ from $\$ 6.7$ billion to $\$ 5.5$ billion as investors apparently wised up to the nature of the fees and switched to ETFs, index funds or funds without sales commissions. Overall, distribution fees increased about $13 \%$ from $\$ 9.8$ billion to $\$ 11.1$ billion.

Advisory Fees. Panel $\mathrm{C}$ of Table 2 reveals that during a period when actively managed fund assets more than doubled, weighted average advisory fees increased slightly and median advisory fees actually increased from seventy-seven to eighty-four basis points. This occurred in spite of a $57 \%$ increase in average fund size from $\$ 1.07$ billion to $\$ 1.68$ billion. There were 1,359 new actively managed funds, a $31 \%$ increase and 230 new fund sponsors, a $45 \%$ increase.

These results are inconsistent with competitive pricing of advisory fees. The median fee increase indicates that new funds and entry of new fund sponsors occurred at higher prices. New entry and competitive pricing would normally result in lower overall prices. Similarly, a 57\% increase in average fund size combined with economies of scale should have resulted in a decline in average advisory fee rates. At a minimum, the decline should have mimicked the fall in administrative fees of about $28 \%$.

The intuition is that the mutual fund advisory function should exhibit scale economies. It should cost little more to manage a $\$ 10$ billion than a $\$ 1$ billion portfolio. The industry itself argued that economies of scale would reduce fees because of increased assets associated with the imposition of distribution fees. ${ }^{26}$ Industry pioneer John Bogle has commented that there are "staggering" economies of scale in the mutual fund business. ${ }^{27}$ A study by McKinsey \& Co. found economies of scale in investment management, administration, marketing and operations in the money management business. ${ }^{28}$ Specifically, investment management costs fall from about thirteen basis points for firms with less than $\$ 25$ billion

26. Id. at 768 .

27. Mutual Fund Industry Practices and Their Effect on Individual Investors: Hearing before the U.S. House of Representatives Subcommittee on Capital Markets, Insurance, and Government Sponsored Enterprises, Committee on Financial Services, 108th Cong. 73 (2003) (testimony of John C. Bogle, President, Bogle Financial Markets Research Service and Found and former Chief Executive, Vanguard Group).

28. McKinsey \& Company, The AsSEt Management Industry in 2010 (2006). 
under management to about six basis points when assets exceed $\$ 100$ billion. $^{29}$

Brown's hypothetical cost curve, grounded in empirically reasonable parameters, shows that increased profit margins of fund to fund sponsors are associated with increased economies of scale. ${ }^{30}$ As discussed below, courts have allowed permissible profit margins as high as $77 \% .{ }^{31}$ Industry average profit margins in the range of 50 to $60 \%$ are common. ${ }^{32}$ Average profit margins on large cap and money market (pre-crash) portfolios of $70 \%$ are also typical. ${ }^{33}$

Other researchers identify what they label as economies of scale. However, the results are ambiguous. Latzko found that expense ratios decrease as assets increase. ${ }^{34}$ Similarly, Investment Company Institute employees have shown that operating expense ratios (advisory plus administrative fees) decrease when assets increase. ${ }^{35}$ These results are consistent with overall economies of scale but fail to differentiate between advisory and administrative scale economies.

Comparative fees charged by the largest fund sponsors offer evidence of economies of scale. There are currently more than 700 firms sponsoring mutual funds. However, the bulk of fund assets are concentrated among a few firms. Panel $\mathrm{C}$ of Table 2 shows that more than $50 \%$ of actively managed mutual fund assets are concentrated in the ten largest mutual fund sponsors or fund families. The twenty largest families manage $65 \%$ of active fund assets.

Panel A of Table 3 shows detail of assets and asset-weighted expenses of the ten largest mutual fund families that offer actively managed openend funds. Of special interest are the fees of the Vanguard family of funds as compared to the other nine families. Vanguard is unique because it is a

29. Id. at 33 .

30. Stewart Brown, Mutual Fund Advisory Fee Litigation: Some Analytical Clarity, 16 J. Bus. \& SEC. L. 329 (2016) (hereinafter "Some Analytical Clarity").

31. Schuyt v. Rowe Price Prime Reserve Fund, Inc., 663 F.Supp. 962, 977, n.77 (S.D.N.Y. 1987).

32. Meyrick Payne \& Sara Yerkey, Mutual Fund Governance Consulting, Industry PRofitability Returns AS Average AsSETS Rise IN 2010 (2010), http://production.mfgovern.com/content/view/108/91/ (last visited Oct. 17, 2017).

33. C. Meyrick Payne \& Sara Yerkey, Profitability Benchmarks in Contract RENEWAL - APRIL 2008 MutuAl Fund Governance Consulting, http://production.mfgovern.com/content/view/71/91 (last accessed Aug. 30, 2017) (hereinafter "Profitability Benchmarks").

34. David A. Latzko, Economies of Scale in Mutual Fund Administration, 22 J. FIN. RES. 331,336 (1999).

35. John D. Rea et al., Operating Expense Ratios, Assets, and Economies of Scale in Equity Mutual Funds, InV. Co. Inst. PersPective, Dec. 1999, at 2, https://www.ici.org/pdf/per05-05.pdf. 
mutual organization and provides its services at cost. Vanguard itself conducts no active management. Rather, it hires sub-advisors to manage its active portfolios. It is noteworthy that each of Vanguard's subadvisors is a for-profit firm and that sub-advisory fees are the result of arm's-length negotiation between Vanguard and the sub-advising firm.

Detail of Top Ten Active and Passive Mutual Funds Families - 2015

\begin{tabular}{|c|c|c|c|c|c|c|}
\hline & & & Total & & & \\
\hline & & & Expense & Advisory & Admin & $12 \mathrm{~b}-1$ \\
\hline Panel A Actively Managed Funds & \# of Funds & ASSETS & Ratio & Fees & Fees & Fees \\
\hline American Funds & 28 & \$1.16 Trillion & 0.680 & 0.303 & 0.140 & 0.237 \\
\hline Fidelity Investments & 309 & \$961 Billion & 0.713 & 0.551 & 0.141 & 0.031 \\
\hline Vanguard & 61 & $\$ 671$ Billion & 0.245 & 0.107 & 0.124 & 0.014 \\
\hline T. Rowe Price & 103 & \$424 Billion & 0.750 & 0.598 & 0.141 & 0.011 \\
\hline Franklin Templeton Investments & 122 & \$334 Billion & 0.908 & 0.543 & 0.133 & 0.232 \\
\hline Pimco & 99 & \$276 Billion & 0.682 & 0.314 & 0.259 & 0.110 \\
\hline Dimensional Fund Advisors & 75 & \$251 Billion & 0.366 & 0.309 & 0.058 & \\
\hline JPMorgan & 160 & \$239 Billion & 0.768 & 0.506 & 0.180 & 0.085 \\
\hline BlackRock & 180 & \$195 Billion & 0.944 & 0.587 & 0.134 & 0.226 \\
\hline Dodge \& Cox & 6 & \$175 Billion & 0.541 & 0.514 & 0.027 & \\
\hline Total Assets of Top Ten Active Fund Families & & $\$ 4.68$ Trillion & & & & \\
\hline Total Assets of Top 9 (No Vanguard) & & \$4.01 Trillion & & & & \\
\hline Asset Weighted Averages & & & 0.641 & 0.401 & 0.138 & 0.105 \\
\hline Asset Weighted Averages (No Vanguard) & & & 0.707 & 0.450 & 0.140 & 0.120 \\
\hline Average Fund Size - Vanguard & & \$11 Billion & & & & \\
\hline Average Fund Size -Other Nine Families & & \$3.84 Billion & & & & \\
\hline & & & Total & & & \\
\hline & & & Expense & Advisory & Admin & $12 b-1$ \\
\hline Panel B Passively Managed Funds & $\#$ of Funds & ASSETS & Ratio & Fees & Fees & Fees \\
\hline Vanguard & 186 & \$1.61 Trillion & 0.079 & 0.006 & 0.063 & 0.011 \\
\hline Fidelity Investments & 73 & \$195 Billion & 0.074 & 0.044 & 0.032 & 0.000 \\
\hline Schwab Funds & 34 & \$48 Billion & 0.180 & 0.133 & 0.048 & 0.000 \\
\hline TIAA-CREF Asset Management & 47 & \$34 Billion & 0.104 & 0.054 & 0.043 & 0.007 \\
\hline AXA Equitable & 32 & $\$ 32$ Billion & 0.586 & 0.332 & 0.116 & 0.139 \\
\hline T. Rowe Price & 5 & $\$ 27$ Billion & 0.279 & 0.125 & 0.155 & 0.000 \\
\hline Jackson National & 29 & \$22 Billion & 0.606 & 0.261 & 0.144 & 0.200 \\
\hline Northern Funds & 18 & \$20 Billion & 0.202 & 0.162 & 0.040 & 0.000 \\
\hline BlackRock & 88 & $\$ 18$ Billion & 0.147 & 0.067 & 0.040 & 0.041 \\
\hline Wells Fargo Funds & 96 & \$17 Billion & 0.483 & 0.349 & 0.143 & 0.004 \\
\hline Total Assets in Top Ten Passive Fund Fam & & \$2.03 Trillion & & & & \\
\hline Total Assets in Top Nine (No Vanguard) & & \$412 Billion & & & & \\
\hline Asset Weighted Averages & & & 0.103 & 0.028 & 0.062 & 0.013 \\
\hline Aceat W/aightad Avaragac / Mn V/ano & & & n 197 & n 111 & ก กא1 & ก ก) \\
\hline
\end{tabular}

Vanguard asset-weighted average advisory fees are 10.7 basis points, less than a fourth of the weighted average of the other large fund families. Moreover, Vanguard's expense ratio is about a third of the weighted average expense ratios of the other nine large fund families. Panel B of Table 3 leads to similar conclusions for passively managed open-end funds. Vanguard and Fidelity charge about eight basis points to manage their various passive products, yet tens of billions of dollars are invested in fund families with expense ratios seven times higher than the Vanguard and Fidelity funds. 
In 2004, Elton, Gruber, and Busse looked at index fund expenses and asked the question: "Are Investors Rational?" They concluded that in a market in which arbitrage is not possible, dominated products can prosper. ${ }^{36}$ Panel B of Table 3 reinforces their conclusions. It shows that tens of billions of dollars are invested in index funds with expenses far higher than essentially identical (except for fees) index funds.

The Elton, Gruber, and Busse results combined with the evidence on fees presented above suggest that the question of investor rationality may apply to all mutual fund investors, not just those who invest in index funds. Consider Panel A of Table 3 where the average Vanguard Total Expense Ratio is roughly one third of the average for the other top nine families yet collectively the other nine have garnered seven times the level of Vanguard actively managed assets. Contrary to surface intuition about mutual fund markets, the collective evidence from Tables 1,2 and 3 demonstrates that mutual fund advisory fees are insulated from market forces.

A fundamental assumption of the model of perfect competition is that market participants are rational and fully informed. There is strong evidence that this is not the case for most mutual fund investors. For instance, the lack of financial literacy on the part of the general public has been well-documented. ${ }^{37}$ Survey research has shown a lack of basic knowledge about funds owned by typical investors. ${ }^{38}$ Another study similarly found that $84 \%$ of investors believe that higher expenses mean better performance. ${ }^{39}$

Palmiter and Taha's survey of the literature on the behavior of mutual fund investors concluded that investors are generally uninformed and lack

36. Edwin J. Elton et al., Are Investors Rational? Choices Among Index Funds, 59 J. Fin. 261, 285-86 (2004).

37. See Annamaria Lusardi, Financial Literacy: Do People Know the ABCs of Finance?, 24 PuB. UndERSTANDING SCI. 260 (2015) (discussing remedies to the lack of financial literacy amongst the United States population); FED. RESEARCH Div., LiBRARY OF Cong., Financial Literacy Among Retail Investors in the United States 1-3 (2011), https://www.sec.gov/news/studies/2012/917-financial-literacy-study-part2.pdf (last visited Oct. 17, 2017) (concluding that Americans lack financial literacy).

38. See Gordon J. Alexander et al., Mutual Fund Shareholders: Characteristics, Investor Knowledge, and Sources of Information, 7 FIN. SERV. REV. 301 (1998) (using a survey of 2,000 randomly selected mutual fund investors to conclude that financial literacy among mutual fund investors needs to be improved); Noel Capon et al, An Individual Level Analysis of the Mutual Fund Investment Decision, 10 J. Fin. SERV. Res. 59 (1996) (finding that grouping investors with those who make similar investment decisions reveals that a small group of highly-skilled investors exists, but that most investors are naïve and unskilled); Peter J. Wallison \& Robert E. Litan, Competitive Equity: A BetTer Way to Organize MutuaL FUNDS (2007) (stating that intermediary boards keep costs high for investors, whom largely lack financial literacy).

39. Brad Barber et al., Out of Sight, Out of Mind: The Effects of Expenses on Mutual Fund Flows, 78 J. Bus. 2095, 2117-18 (2005). 
financial sophistication. ${ }^{40}$ They noted that the industry and the SEC are generally much more sanguine about the ability of fund investors to discipline fees. ${ }^{41}$ Brown argues that the investment management industry has effectively captured the SEC and illustrates this with examples of the Commission's failure to force disclosure of important information. ${ }^{42}$

The tax code introduces frictions that make it difficult for many investors to switch to low cost funds. A fund held for a long time is likely to have achieved significant capital gains, the taxation of which would swamp cost savings for many years. ${ }^{43}$ In addition, most $401 \mathrm{~K}$ retirement plans contain a limited menu of funds and many fail to include low cost

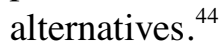

Conflicts of interest impose significant costs on naïve and inexperienced investors. Many stockbrokers, investment advisors and financial planners are compensated by commissions on mutual funds, providing an incentive to recommend funds with front loads or fund classes with distribution fees. ${ }^{45}$

The evidence that active mutual fund management is unable to consistently outperform passive management is well known, ${ }^{46}$ yet currently more than nine trillion dollars is invested in actively managed mutual funds. ${ }^{47}$ The overall decrease in mutual fund fees between 2005 and 2015

40. Alan R. Palmiter \& Ahmed E. Taha, Mutual Fund Investors: Divergent Profiles, 2008 Colum. Bus. L. Rev. 934, 936 (2008).

41. Id.

42. See Regulatory Capture, supra note 13, at $730-45$ (explaining how the SEC prioritizes non-disclosure of industry costs over investors' interests).

43. To illustrate, assume that $\$ 10,000$ is invested in a fund that experiences a 5\% per year capital appreciation. After ten years, the fund would be worth about $\$ 16,300$ and if sold would generate a capital gains tax of about $\$ 1,250$ if the capital gains tax rate were twenty percent. If the difference $(\$ 15,050)$ was reinvested in a fund with a twenty-five basis point lower advisory fee, it would take more than thirty years for the value of the lower expensed fund to equal that of the higher expense fund.

44. Ian Ayres \& Quinn Curtis, Beyond Diversification: The Pervasive Problem of Excessive Fees and "Dominated Funds" in 401(k) Plans, 124 YALE L.J. 1476, 1481 (2015).

45. Inv. Co. Inst., 2017 InveSTMENT COMPANy FACTBOOK, 102 (2017). As of the end of 2016, about $\$ 1.9$ trillion worth of asset funds carried a front load. Id. at 106, fig.5.13.

46. See Martin J. Gruber, Another Puzzle: The Growth in Actively Managed Mutual Funds, 51 J. FIN. 783, 790 (1996) (considering why investors buy into actively managed mutually funds even though they have lower returns compared with index funds); Michael C. Jensen, The Performance of Mutual Funds in the Period 1945-1964, 23 J. Fin. 389, 415 (1968) (finding that actively managed mutual funds did not outperform funds with a buy-themarket-and-hold policy); Lyman Johnson, A Fresh Look at Director "Independence": Mutual Fund Fee Litigation and Gartenberg at Twenty-Five, 61 VAND. L. REV. 497 (2008); Burton G. Malkiel, Returns from Investing in Equity Mutual Funds 1971 to 1991, 50 J. Fin. 549, 571 (1995) (concluding that passive management funds have advantages over active management funds, which generally fail to provide excess returns).

47. Supra Table 1. 
was caused largely by some investors switching to passively managed funds, ETFs and index funds. ${ }^{48}$ There is little or no evidence that fees on actively managed funds have been responsive to competitive pressures. ${ }^{49}$ Thus, the observation that dominated products can prosper in a market in which arbitrage is not possible ${ }^{50}$ holds for actively managed funds as well as index funds.

To summarize, in the 2005 to 2015 period, actively managed mutual fund assets more than doubled. Yet, advisory fees were essentially flat. This is both interesting and essentially inexplicable in economic terms. The explanation lies in the legal and regulatory realm in which mutual fund sponsors operate and it is to that realm we now turn.

\section{LEGAL AND REGULATORY UNDERPINNINGS OF MUTUAL FUND ADVISORY FEES}

In the 1920s and 1930s, the mutual fund industry suffered from a multitude of abuses including self-dealing, excessive fee levels, improperly valued securities, and misleading advertising and accounting practices. ${ }^{51}$ The ICA dealt effectively with most of these problems. Congress included in the ICA a provision directing the SEC to study the impact of investment company growth and submit a report to Congress at a later date. In 1958, the SEC commissioned the Wharton School of Finance to prepare a study of the effects of the growth in the industry. The Wharton Study ${ }^{52}$ and a subsequent SEC report ${ }^{53}$ included legislative recommendations.

The essential insight of the Wharton study and PPI report was that advisory fees on mutual funds are too high because funds are captives of the investment management firm and there is no effective competition for managerial services. ${ }^{54}$ Investment management contracts cannot be terminated except in extreme circumstances, and fund directors are therefore limited in the scope of fee negotiations. ${ }^{55}$

48. See supra p. 9 (explaining that much of the decrease in open-end funds can be attributed to investors switching from actively to passively managed funds).

49. Infra p. 24.

50. Elton, supra note 36.

51. Amy B. Lancellotta, Paulita A. Pike \& Paul Schott Stevens, Fund Governance: A Successful, Evolving Model, 10 VA. L. \& Bus. ReV. 455, 458-89 (2016).

52. Wharton Sch. of FinAnCE And COMmerce, A Study OF Mutual Funds, H.R. Rep. No. 87-2274 (1962), http:// sechistorical.org/museum/papers/1960/ (hereinafter "Wharton Study").

53. U.S. Sec. \& Exch. Comm'n, Public Policy Implications Of Investment COMPANY GROWTH, H.R. REP. No.89-2337 (1966), http://www.sechistorical.org/museum/papers/1960/ (hereinafter "PPI Report").

54. PPI Report at 64.

55. See Anita K. Krug, Investment Company as Instrument: The Limitations of the 
The Wharton study found that mutual fund advisory fees tended to cluster around fifty basis points. ${ }^{56}$ More than $72 \%$ of advisers charged that rate or more in $1960 .^{57}$ The study found that mutual fund fees were generally not responsive to asset levels. ${ }^{58}$ In a near majority of cases, mutual fund advisory fees were two or more times as high as those imposed on other clients. ${ }^{59}$ In about $15 \%$ of the cases, mutual funds were charged more than five times the level of other advisory clients. ${ }^{60}$

The ICA mandates that $40 \%$ of a fund's directors or trustees be unaffiliated with the fund ${ }^{61}$ sponsor and that the unaffiliated directors "negotiate" advisory fees with the fund sponsor. ${ }^{62}$ The study stated that unaffiliated directors "may be of restricted value as an instrument for providing effective representation of mutual fund shareholders in dealings between the fund and its investment adviser." ${ }^{, 3}$

The PPI report found similar results. In 1965, fifty-seven mutual funds with assets of at least one hundred million dollars had a median advisory fee of forty-eight basis points (a decrease from fifty to forty-eight basis points caused by litigation settlements in lawsuits filed following the release of the Wharton Study). ${ }^{64}$ The average (unweighted) advisory fee was forty-five basis points. ${ }^{65}$

The study looked at the fee schedules of annual advisory fee rates to manage a hundred-million-dollar portfolio published by six leading banks. The annual fee for five of the six banks amounted to six basis points, a rate less than one eighth of the fifty basis points commonly charged to mutual funds of that size. ${ }^{66}$ The sixth bank charged seven basis points. ${ }^{67}$ Moreover, the study noted that banks absorbed some costs for marketing and custodial services that were handled under separate contracts for mutual funds. ${ }^{68}$

Corporate Governance Regulatory Paradigm, 86 S. CAL. L. REv. 263, 273-74 (2013) (explaining that terminating the investment advisor is complicated because the advisor's role constitutes the core of the company).

56. Wharton Study, supra note 52, at 490.

57. Id. at 482-83.

58. Id. at 484 and 490 .

59. Id. at 489 .

60. Id. at 489. In nine instances the fee rate charged open-end companies was five or more times as high as that charged all other clients.

61. 15 U.S.C. $\$ 80 a-10$ (a) (2012).

62. 15 U.S.C. $\$ 80 a-15$ (c) (2012).

63. Wharton Study, supra note 52, at 34.

64. PPI Report, supra note 53, at 11.

65. Id.

66. Id. at 115 .

67. Id.

68. Id. at 116 . 
Both the Wharton study and the PPI report found that advisory fees were too high relative to fees negotiated at arm's length. Both studies identified a systemic problem and showed excessively high fee levels in the industry as a whole. Both studies were also skeptical of the efficacy of unaffiliated directors to negotiate advisory fees: "It has been the Commission's experience in the administration of the Act that in general the unaffiliated directors have not been in a position to secure changes in the level of advisory fees." 69

Following is a quote from the Letter of Transmittal from the SEC to Congress:

The report concludes that mutual fund shareholders need protection against incurring excessive costs in the acquisition and management of their investments and that, given the structure and incentives prevailing in the industry, neither competition nor the few elementary safeguards against conflict of interest deemed sufficient in 1940 and contained in the Investment Company Act presently provide this protection in adequate measure. It is recommended that the statute be amended to expressly require that the compensation received by persons affiliated with investment companies, including their management organizations, for services furnished to an investment company be reasonable, and that this standard be enforceable in the courts. ${ }^{70}$

Before the 1970 amendments, the leading case concerning the excessiveness of advisory fees applicable to mutual funds, a decision of the Delaware Court of Chancery, stated the rule as:

[W] hether what the corporation has received is so inadequate in value that no person of ordinary, sound business judgment would deem it worth what the corporation has paid. If it can be said that ordinary businessmen might differ on the sufficiency of the terms, then the court must validate the transaction. ${ }^{71}$

There was intense debate in Congress in the three years leading up to passage of the 1970 amendments regarding the standard that should be adopted for services furnished to an investment company to replace the Saxe-Brady "corporate waste" standard. Bills introduced in the House in $1967^{72}$ and the Senate in $1968^{73}$ adopted the SEC's "reasonableness" standard. Industry opposition to the bills argued that allowing the courts to

69. Id. at 131 .

70. Id. at viii.

71. Saxe v. Brady, 184 A.2d 602, 610 (Del. Ch. 1962).

72. See H.R. 9510, $\S 8(d), 90$ th Cong. ( $1^{\text {st }}$ Sess. 1967) (setting forth factors to consider in determining the reasonableness of the compensation)).

73. S. $3724, \S 8$. 
determine whether a management fee was reasonable would turn the ICA into a ratemaking vehicle ${ }^{74}$ and allow the courts to substitute their own business judgment for that of fund directors. ${ }^{75}$ The minority views in the 1968 Senate Committee Report echoed the industry's opposition to what it characterized as the ratemaking nature of the proposed amendments. ${ }^{76}$ The 1967 and 1968 legislation failed and with it the SEC's proposed reasonableness standard.

Between the end of the 1968 legislative session and additional Congressional hearings in 1969, members of the House and Senate committees drafting revised legislation met several times with officers of the Investment Company Institute. ${ }^{77}$ As a result, the 1970 amendments to the ICA removed the "reasonableness" standard opposed by the ICI, made investment advisers "fiduciar[ies]" with respect to fees,${ }^{78}$ and gave investors a private cause of action. ${ }^{79}$ Although Congress left it to the courts to determine an appropriate standard to gauge whether a particular fee violated the investment adviser's fiduciary duty, ${ }^{80}$ the Senate Report provides the courts some guidance regarding the intent of the legislation:

In reporting this bill, your committee recognizes the importance of permitting adequate compensation and incentives so that men of ability and integrity will continue to be attracted to the mutual fund industry .... [T] he forces of arm's-length bargaining do not work

74. Investment Company Act Amendments of 1967: Hearings on H.R. 14742 Before the Subcomm. on Commerce and Fin. of the House Comm. on Interstate and Foreign Commerce, 90th Cong. 382 (1967) (statement of Phil E. Pearce, Chairman, Board of Governors, National Association of Securities Dealers). The reasonableness standard was endorsed by the American Bankers Association, however; see Investment Company Amendments Act of 1968, S. Rep. 90-1351, at 2-3 (1968).

75. Lancellotta et al., supra note 51 , at 467.

76. S. Rep. No. 90-1351, supra note 74, at 40.

77. Hearings on S. 34 and S. 296 Before the S. Comm. on Banking and Currency, 91st Cong. 8 (statement of Hugh F. Owens, Commissioner, SEC). See also Hearings on H.R. 11995, S. 2224, H.R. 13754, and H.R. 14737 Before the H. Comm. on Commerce and Fin. Of the Comm. on Interstate and Foreign Commerce, 91st Cong. (1969) (statement of Hamer H. Budge, Chairman, SEC) (“...Chairman Sparkman stated that this bill was worked out between the industry and the Commission as well as with members of his committee.")

78. See Investment Company Amendment Act of 1970, Pub. L. No. 91-547, § 35(b), 84 Stat. 1413 (1970) (codified as amended at 15 U.S.C. § 80a-35 (2012)) (explaining that investment advisors are deemed to have a fiduciary duty with respect to compensation for their services).

79. Id.

80. Tory L. Lucas, Judge Not Under an Unjust Standard: Why an Investment Adviser's Fiduciary Duty as to Fees under Section 36(B) of the Investment Company Act of 1940 is Illusory and Unjust Until an Adjudicated Case Illustrates a Breach of the Fiduciary Duty, 9 LiBerTy U. L. Rev. 469, 513 (2015); see Gartenberg v. Merrill Lynch Asset Mgmt., Inc., 694 F.2d 923, 928 (2d Cir. 1982) (Congress made ... "no attempt to set forth a definitive test by which observance or breach of fiduciary duty was to be determined."). 
in the mutual fund industry in the same manner as they do in other sectors of the American economy .... . [Y]our committee has decided that there is an adequate basis to delete the express statutory requirement of 'reasonableness,' and to substitute a different method of testing management compensation. This bill states that the mutual fund investment advisor has a specific 'fiduciary duty' in respect to management fee compensation .... . Your committee recognizes the fact that the investment adviser is entitled to make a profit... . [I]t is not intended to introduce general concepts of rate regulation as applied to public utilities . . . . This section is not intended to authorize a court to substitute its business judgment for that of the mutual fund's board of directors in the area of management fees ... . This provision does not represent a finding by the committee as to the level of fees in the industry. Your committee does not believe itself qualified to make such judgments. Nor is it contemplated that the Commission will seek a general reduction of fees on an industrywide basis. ${ }^{81}$

In the 1970 legislation, Congress totally repudiated the findings of experts at the Wharton School of Finance and the SEC that management fees were too high in the whole system and that fund directors were ineffective in policing fees. The Committee did not feel qualified to make judgments concerning the level of fees in the industry but did feel qualified to direct the SEC not to seek a general reduction in fees. In addition, the Committee directed the courts to give deference to mutual fund directors. ${ }^{82}$

The Wharton study and PPI report presented Congress with a visible political problem: structurally, management fees are not subject to arm's length negotiations and are systemically higher than fees that are subject to competition. Making advisers fiduciaries was the purported solution to the problem. However, the Senate Report signaled a very different intent and the judicial system got the message.

Courts enforce laws as written, taking into account the underpinning legislative intent of Congress. In this case, the judicial system was given clear marching orders: legislative intent was crystal clear - Congress was endorsing the status-quo of high fees. The judicial system complied, and case law precedents support the status quo that existed in 1966 and that exists today.

81. Investment Company Amendments Act of 1969, S. Rep. 91-184, at 4-7 (1969).

82. Congress was more circumspect in the actual language of the statute. Section 35(b) states that a reviewing court should take into account fund directors' approval of an adviser's management contract by "giving such consideration ... as is deemed appropriate under all the circumstances.” 15 U.S.C. $§ 80 a-36(b)(2)(2012)$. 
The enacted legislation curtailed fund sponsor exposure to damages. It provided only a one-year lookback damage period that effectively limited monetary penalties and reduced any serious deterrent effect. This reinforces the insight that the 1970 Amendment favored the investment management industry at the expense of individual investors.

The results of fee litigation since the passage of the 1970 Amendment support the proposition that the playing field is tilted towards the investment management industry. Just as no plaintiff ever recovered under the pre-1970 state common law "corporate waste" standard ${ }^{83}$ no plaintiff has ever received an award for excess fees under section 36(b).$^{84}$ This remains true in 2017. Yet advisory fees are essentially the same or higher than they were in 1960 and 1965 when the Wharton School and the SEC conducted their studies. Table 4 compares assets and average/median fees in $1960,1965,2005$, and 2015. In spite of vigorous growth in assets and mutual funds offered, average and median fees increased from 1960-65 to 2005 and 2015. The evidence presented below shows that advisory fees continue to far exceed fees subject to competitive forces.

\section{Table 4}

\begin{tabular}{|c|c|c|c|c|}
\hline & 1960 & 1965 & 2005 & 2015 \\
\hline Total Mutual Fund Assets & \$17 Billion & \$35 Billion & $\$ 4.6$ Trillion & $\$ 9.5$ Trillion \\
\hline Number of Mutual Funds & 161 & 170 & 4315 & 5674 \\
\hline Median Advisory Fee & 0.5 & 0.48 & 0.77 & 0.84 \\
\hline Average Advisory Fee & & 0.45 & 0.53 & 0.532 \\
\hline
\end{tabular}

The investment management industry and the judicial system faced certain problems in maintaining the status quo. In spite of laws passed by Congress, the laws of economics are stubborn things and remained in

83. See 114 Cong. Rec. 23301 (July 25, 1968) (statement of Sen. Bennett) (“.[I]n every case, the court has determined that on the basis of the information available, the fee was reasonable or at least within the law."). See also Hearings on S. 34 and S. 296 Before the S. Comm. on Banking and Currency, 91st Cong. 20 (statement of Philip A. Loomis, Jr., General Counsel, SEC) ("No shareholder has successfully recovered in suits on management fees"); $i d$. at 107 (colloquy between Sen. Proxmire and Robert L. Augenblick, President, ICI) ("Sen. Proxmire: Can you give me an example of any instance at all in history in which a plaintiff has ever won a suit to reduce management fees? Mr. Augenblick: So far as I know, there have been three litigated cases, and in none of these cases was the plaintiff successful.")

84. James D. Cox et. al, Securities Regulation: Cases and Materials (6th ed. 2008). 
effect. The principal problem was that fees actually determined by arm's length bargaining did not disappear. To avoid the inconvenient comparison of fees over time, the investment management industry settled cases that might result in bad precedent and allowed to be brought to trial only cases that allowed the judiciary to find favorable outcomes.

\section{A. The Judiciary Weighs In}

We now turn to the important judicial decisions that facilitated maintenance of the status quo.

\section{The Business Judgment Rule - Burks v. Lasker}

The Business Judgment Rule (business judgment rule) is a judicially created doctrine in corporation law that requires courts to defer to the business judgment of corporate executives. The basic notion is that corporate boards are presumed to act in the best interests of shareholders and that courts should not second guess directors. Directors are not liable for errors in judgment if they act in good faith with due care. The genesis of the business judgment rule for mutual funds are statements by the President of the Investment Company Institute in the narrow context of the SEC's proposed reasonableness standard. ${ }^{85}$ The 1969 Senate Report casually broadened the concept. ${ }^{86}$

In design and operation, mutual fund governance is much different from normal corporate governance. Effectively, core business decisions impacting the fund are made by the investment management firm sponsoring the funds. Mutual fund boards are dominated by its officials who have a clear conflict of interest because in effect they represent both fund shareholders and the investment management firm. By limiting the mandatory number of "independent" directors to $40 \%$ of the board, Congress designed the ICA to preclude independent directors from having veto power over core business decisions of the fund.

In Burks v. Lasker (Burks), ${ }^{87}$ fund shareholders brought suit against the adviser and certain board members alleging lack of due care in the

85. Investment Company Amendments Act of 1969: Hearings Before the Comm. on Banking and Currency on S. 34 and S. 296, 91st Cong. 107 (1969) (Statement of Robert L. Augenblick, President and General Counsel, Investment Company Institute); Mutual Fund Amendments: Hearings on H.R. 11995, S. 2224, H.R. 13754, and H.R. 14737 Before the Subcomm. on Commerce and Fin. of the H. Comm. on Interstate and Foreign Commerce, 91st Cong. 438 (1969) (Statement of Robert L. Augenblick, President and General Counsel, Investment Company Institute).

86. Supra note 81 , at 6 .

87. (holding that a disinterested, fully informed director decision to terminate derivative 
purchase of Penn Central notes that subsequently defaulted. The court noted that the ICA assigns to independent directors the role of "watchdog" for fund shareholder interests. ${ }^{88}$ The independent directors approve the annual investment management contract that determines fees paid by shareholders and have other duties in areas in which the board can be conflicted. In concluding that federal courts should apply state law governing the authority of independent directors to discontinue such derivative suits, the Supreme Court effectively enshrined the business judgment rule, developed in the corporate law context, in mutual fund case law. ${ }^{89}$ As a result of Burks, cases became harder for plaintiffs to win.

Burks and subsequent similar decisions are consistent with the overall intent of Congress to maintain the status quo of mutual fund fees. Langevoort argues, correctly, that Burks was pivotal in reducing the level of judicial scrutiny in breach of fiduciary duty cases, although the unique nature of mutual fund governance makes it a mistake to reason by analogy to governance in other types of corporations. ${ }^{90}$

Debate in the literature concerning the efficacy of mutual fund governance continues. Palmiter argues that fund independent directors,

[A]pprove fund transactions with the management firm and ensure compliance with the 1940 Act and implementing SEC rules. Fund directors thus function as outsourced regulators, with their selection and compensation in the hands of the management firm they supervise.... Fund boards have been weak and even feckless protectors of fund investors .... ${ }^{91}$

According to the Investment Company Institute, however, mutual fund governance could serve as a model for all of corporate America. ${ }^{92}$ Lancellotta, Pike \& Stevens are also supportive. ${ }^{93}$

litigation should be upheld as an exercise of their business judgment).

88. Id. at 483 .

89. See Id. at 487 (Stewart, J., concurring) (likening the decision of whether to sue an alleged wrongdoer with any other corporate decision, decisions which are the purview of the board).

90. Donald J. Langevoort, Private Litigation to Enforce Fiduciary Duties in Mutual Funds: Derivative Suits, Disinterested Directors and the Ideology of Investor Sovereignty, 83 WASH. U. L. Q. 1017-19 (2015).

91. Alan R. Palmiter, The Mutual Fund Board: A Failed Experiment in Regulatory Outsourcing, 1 BrooK. J. CoRP., Fin. \& COM. L. 165 (2006).

92. See Richard M. Phillips, Mutual Fund Independent Directors: A Model for Corporate America, Inv. Co. Inst. Perspective, Aug. 2003, at 2, https://www.ici.org/pdf/per09-04.pdf (last accessed Aug. 30, 2017) (citing the Congressional response to Enron-Worldcom as legislation emulating the corporate governance model for investment companies under the Investment Company Act of 1940).

93. Amy B. Lancellotta et. al, Fund Governance: A Successful, Evolving Model, 10 VA. L. \& Bus. Rev. 455 (2016) (Paul Schott Stevens is President and CEO of the investment 
Others are largely skeptical of the efficacy of fund governance. ${ }^{94}$ One study showed that the connections between directors and management firms impact the decision to hire sub-advisers, ${ }^{95}$ while another found evidence that higher paid independent fund directors approve higher shareholder fees. ${ }^{96}$ In an exemplary review written subsequent to the mutual fund scandals of 2003, Birdthistle found evidence of "camouflaged extractions of shareholder value," i.e., rents on the part of the investment management industry. Among other things, fund governance failed to detect or prevent large-scale market timing and late trading that cost fund investors billions of dollars. ${ }^{97}$

The evidence seems to support the Palmiter position that fund boards have been weak and feckless. As one lawyer who testified at the 1969 Senate hearings said, "[t]he testimony in our litigations shows the unaffiliated directors passive to the point of somnolence, while the advisory fees mounted year after year to figures of shocking magnitude." 98

Examination of Table 4 shows that independent fund directors remain "somnolent." Between 2005 and 2015, dollar advisory fees, the product of percentage fees and fund assets, increased from about $\$ 24$ billion to about $\$ 50$ billion. In a recent case, the judge chastised the independent directors because although the directors were represented by counsel and were provided with detailed materials to which they and the defendants can point to and say, "see how thorough and careful we were," the entire process

Company Institute).

94. See David J. Carter, Mutual Fund Boards and Shareholder Action, 3 VILL. J.L. \& INV. MGMT. 6 (2002) (questioning the theoretical viability of fund governance due to a belief that the interests of independent mutual fund directors may be closely aligned with those of interested directors); Freeman-Brown, supra note 15 (arguing that interests of a fund's board are aligned with the investment adviser, rather than the shareholders); Lyman Johnson, $A$ Fresh Look at Director "Independence": Mutual Fund Fee Litigation and Gartenberg at Twenty-Five, 61 VAND. L. REV. 497 (2008) (sharing inconclusive empirical evidence on the relationship between mutual fund director independence and mutual fund advisory fees); Eric D. Roiter, Disentangling Mutual Fund Governance from Corporate Governance, 6 HARV. Bus. L. REV. 1 (2016) (arguing that fundamental differences between mutual funds and corporations necessitate a disentanglement of mutual fund governance from corporate governance).

95. Camelia M. Kuhnen, Business Networks, Corporate Governance and Contracting in the Mutual Fund Industry, 64 J. FIN. 2185, 2187 (2009) (hereinafter "Kuhnen").

96. Peter Tufano \& Matthew Sevick, Board Structure and Fee-setting in the U.S.Mutual Fund Industry, 46 J. FIN. ECON. 321 (1997).

97. William A. Birdthistle, Compensating Power: An Analysis of Rents and Rewards in the Mutual Fund Industry, 80 TuL. L. REv. 1401, 1451 (2006) (hereinafter "Birdthistle").

98. Investment Company Amendments Act of 1969: Hearings Before the S. Comm. on Banking and Currency, 91st Cong. 179 (1969) (statement of Abraham L. Pomerantz, New York Bar); see also Amy B. Lancellotta et al, Fund Governance: A Successful, Evolving Model, 10 VA. L. \& Bus. Rev. 455, 465 (2016) (citing to the Pomerantz quote). 
seems less a true negotiation and more an elaborate exercise in checking off boxes and papering the file. ${ }^{99}$ Nevertheless, the plaintiffs lost the case.

\section{The Fiduciary Standard - Gartenberg v. Merrill Lynch}

In the years after the 1970 amendments, the investment management industry settled or otherwise disposed of six fee cases filed under section 36(b). ${ }^{100}$ Only following the U.S. Supreme Court's decision in Burks in 1979 , did the industry allow to be brought to trial a case that would establish the fiduciary standard for what constitutes an excessive fee. ${ }^{101}$

The Merrill Lynch Ready Assets Trust ("the Trust"), a money market fund, was ideally suited for industry purposes because of certain anomalous features not common to funds in general. The Trust was unique in that the fund was integrated into the Merrill Lynch brokerage operation in what were known as Cash Management Accounts (CMAs). Such accounts effectively circumvented banking laws that prevented banks from paying interest on checking accounts. ${ }^{102}$ In the then paper-based financial world, a stock transaction took several steps: a broker took a customer's stock order by phone, filled out a trade ticket, had the ticket entered into an electronic system, and then wired the transaction to the trading floor for execution. ${ }^{103}$ Each stock transaction in a CMA generated an equal and opposite money fund transaction: each stock trade ticket correspondingly credited or debited (depending on the stock trade) the money fund. The brokerage operation, under Merrill Lynch's internal accounting procedures, received processing costs from the money fund. Merrill Lynch conducted internal time and motion studies to estimate the incremental expenses involved. ${ }^{104}$

Plaintiffs sought to compare the fund's advisory fees with fees actually determined by arm's length bargaining, as had been done in the Wharton study and PPI report. The industry successfully argued that institutional accounts have lower management costs and thus higher fees on mutual funds are justified. ${ }^{105}$ The appellate court disallowed the plaintiff's

99. In re Am. Mut. Funds Fee Litig., 2009 WL 5215755 (C.D. Cal. 2009).

100. See Some Analytical Clarity, supra note Error! Bookmark not defined., at 354-55 ( summarizing the six cases).

101. See Gartenberg v. Merrill Lynch Asset Mgmt., Inc., 694 F.2d 923, 923 (2d Cir. 1982) (holding that a fund manager's fiduciary duty is assessed under a reasonableness standard).

102. See Some Analytical Clarity, supra note 30, at 356 (detailing the operation of the Trust).

103. Id.

104. See Anita Ingrid Lotz, Deregulation or Regulation: Money Market Mutual Funds and Other Illegitimate Offspring of the Banking and Securities Industry, 1 ANN. REv. BANKING 187, 196 (1982) (detailing the operation of the CMAs); see also Gartenberg, 694 F.2d at 931 (referenced therein as the "Fitz-Gerald estimate").

105. See Gartenberg, 694 F.2d at 930 (ruling that under section 36(b) of the Investment 
comparison of the Merrill Lynch advisory fees with fees charged to pension funds because the "nature and extent of the services required by each type of fund differ sharply. As the district court recognized, the pension fund does not face the myriad of daily purchases and redemptions throughout the nation which must be handled by the Fund . . .."106

In all but a few unique funds in the 1970s and early 1980s, however, managers of mutual fund portfolios were (and remain) insulated from all contact with individual investors. Separate distribution and transfer agency contracts cover interactions with investors, ${ }^{107}$ a deceptive industry strategy only recently brought to light. ${ }^{108}$ The precedent of not allowing advisory fee comparisons with pension and other institutional fees continues today, despite the anomalous nature of the Merrill Lynch fund's processing costs.

The Gartenberg court articulation of a fiduciary standard to gauge fee excessiveness also remains in place: "To be guilty of a violation of $\$ 36(\mathrm{~b})$, therefore, the adviser-manager must charge a fee that is so disproportionately large that it bears no reasonable relationship to the services rendered and could not have been the product of arm's-length bargaining."109

The standard involves a two-pronged test: the fee at issue must be "so disproportionately large" that it "could not have been the product of arm'slength bargaining." As Lyman Johnson has observed, "the court illogically framed the first prong in a way that deviates from 'reasonableness' and seemed to require extremeness - 'so disproportionately large,' not just 'disproportionately large,' and 'no reasonable relationship,' not just 'unreasonable'.,110

Contrary to Johnson, the court's framing of the standard is not illogical at all. The standard is extreme and entirely consistent with the legislative intent of the 1970 amendments that were written to favor the investment management industry at the expense of individual investors. ${ }^{111}$ Application of the standard is essentially determined by the subjective judgment of the judiciary.

The appellate court also identified the elements, known as the Gartenberg factors, that future courts should examine when applying the standard. These included the profitability of the fund to the fund sponsor

Company Act, the correct standard to assess if a fund manager accomplished its fiduciary duty is a reasonableness standard).

106. Id.

107. See Some Analytical Clarity, supra note 30, at 342 (detailing various contracts' coverage of interactons with investors).

108. Some Analytical Clarity, supra note 30.

109. Gartenberg, 694 F.2d at 928.

110. Johnson, supra note 46, at 516.

111. Supra note 81 , at 4-7. 
and economies of scale. Different processing cost estimates confounded the court's ability to establish standards for these factors. Brown estimated that the gross profit margin of the fund to Merrill Lynch, exclusive of processing costs, was approximately $96 \%{ }^{1{ }^{12}}$ Estimates of marginal processing costs yielded a profit margin of about $70 \%,{ }^{113}$ although other estimates suggested that Merrill Lynch was losing money on the fund. ${ }^{114}$ It was left to a subsequent court to establish a profit margin standard.

\section{The Profit Margin Standard - Schuyt v. Rowe Price Prime Reserve Fund, Inc.}

Unlike Gartenberg, the money market fund in Schuyt v. Rowe Price Prime Reserve Fund, Inc. (Schuyt) ${ }^{115}$ was not integrated into a brokerage firm and had no processing costs. The fund had a TA to handle interactions with investors.

The judge in Schuyt chose to ignore expert economic testimony because the economic experts failed to analyze how the fund board negotiated the advisory contract. He also denied any comparison of the fund's advisory fee with fees charged institutional customers. The judge accepted the profit margin calculation of plaintiff's expert: $59.1 \%$ in 1979, $66.8 \%$ in 1980 and $77.3 \%$ in $1981 .^{116}$ The subjective nature of the Gartenberg Standard was in full view in the decision:

While it cannot be denied that the Adviser earned a significant profit from these services, it does not appear to the Court, in light of all of the facts, that the fees charged by the Adviser were so disproportionately large that they bore no reasonable relationship to the services rendered and could not have been the product of arms-length bargaining. ${ }^{117}$

112. Some Analytical Clarity, supra note 30 , at 361 .

113. Id. at 362 .

114. Id. at 361 .

115. See 663 F. Supp. 962, 962 (S.D.N.Y. 1987) (holding that T. Rowe Price did not breach its fiduciary duty by charging excessive fees under section 36(b) of the Investment Company Act).

116. Id. at 989 .

117. The court, relying on the business judgment rule to justify its decision, hedged its opinion somewhat in a footnote: "The Court wishes to make clear that it is not holding that a profit margin of up to $77.3 \%$ can never be excessive. In fact, under other circumstances, such a profit margin could very well be excessive. For example, if advisory services being challenged were not of the highest quality and if the directors were not so obviously qualified, fully informed, and conscientious, a similar fee structure could violate section 36(b)." Id. at 989 n. 77. 
The Schuyt court's finding that a $77 \%$ profit margin was not excessive continues to be used as a guideline by courts today. It represents a very high hurdle for plaintiffs to prove a breach of fiduciary duty in mutual fund fee cases. Profit margin data on individual funds are proprietary in nature and seldom available outside of the litigation process where they are subject to severe confidentiality agreements. However, summary numbers are available from a Mutual Fund Governance consulting organization and these numbers indicate that profit margins in the range of 50 to $60 \%$ are the norm in the industry. ${ }^{118}$

\section{The Vanguard Exception - Kalish v. Franklin Advisers}

Kalish v. Franklin Advisers, Inc. (Kalish), ${ }^{119}$ decided subsequent to Gartenberg and Schuyt, involved a GNMA fund, operated by Franklin Advisors, a for-profit company. Franklin Advisors paid for advisory and administrative services under a single unified contract that included services for underwriting, TA, management and other items. The fund had an expense ratio of $.545 \%{ }^{120}$ and an advisory fee over the period in question of $.45 \% .^{121}$

Plaintiffs in Kalish argued that the Franklin GNMA fund fees were excessive relative to a comparable Vanguard GNMA fund. ${ }^{122}$ Defendants contended that Vanguard comparison was inappropriate because the Vanguard family of funds owned the management company, and thus rendered services to the funds at cost, whereas Franklin Advisers sought to make a profit. ${ }^{123}$

The administrative services provided to the Vanguard GNMA fund at cost were of two types: advisory services and all other administrative services. The advisory services were provided by a sub-advisory contract with Wellington Management, a for-profit company, who managed the portfolio for three basis points, while still making a profit. The entire expense ratio of the Vanguard fund was thirty-five basis points. ${ }^{124}$ The court's analysis of the unified fee failed to analyze the advisory services separately from the administrative services thereby corrupting the results. Vanguard advisory fees are a good proxy for institutional fees because they

118. See Payne \& Yerkey, supra note 32.

119. See 742 F. Supp. 1222 (S.D.N.Y. 1990) (holding that Franklin Advisers' fees were reasonable and not in violation of the Investment Company Act).

120. Id. at 1230 .

121. Id. at 1240 .

122. Id. at 1230 .

123. Id.

124. Id. at 1231. 
are competitively negotiated, but after Kalish, no subsequent case has allowed the comparison.

\section{B. Updating the Wharton Study and PPI Report}

In the early 2000s, research by Freeman and Brown upset the status quo. ${ }^{125}$ Their research updated the Wharton study and PPI report and found that mutual fund advisory fees continue to exceed comparable institutional fees, ${ }^{126}$ evidence that the 1970 Amendment to the ICA, which made investment advisers fiduciaries with respect to fees, did not effectively deal with the problem. The investment management industry sponsored research promoting contrasting views concerning the competitive nature of mutual fund "markets." 227 In reviewing the decision of the Seventh Circuit Court of Appeals that disapproved the Gartenberg approach, the U.S. Supreme Court in Jones v. Harris Assocs. L.P. (Jones) ${ }^{128}$ affirmed the Gartenberg standard and stated that any review of a long-settled standard such as Gartenberg "is a matter for Congress, not the courts." ${ }^{29}$ In this section, we examine the new evidence, the industry response, and the U.S. Supreme Court decision in Jones.

Freeman-Brown obtained fee information from large public pension funds on equity portfolios managed by external investment advisory firms. ${ }^{130}$ They analyzed 220 actively managed public pension portfolios with about $\$ 100$ billion in assets ${ }^{131}$ and compared these fees to similar mutual funds. Table 5 presents the results. Weighted average pension fees were twenty-eight basis points while mutual fund fees were fifty-six basis points. Thus, the Wharton and PPI-documented differences between mutual fund advisory fees and fees subject to arm's length bargaining continued for more than a quarter century after the Wharton study and PPI report.

125. Freeman-Brown, supra note 15.

126. Id. at 672 .

127. Infra at 136 .

128. See 559 U.S. 335, 338 (2010) (reaffirming Gartenberg formulation of Section 36(b) of the Investment Company Act that imposes liability on investment adviser fees only when they are so disproportionately large that they bear no reasonable relationship to the services rendered and could not have been the product of arm's length bargaining).

129. Id. at 353 .

130. Freeman-Brown, supra note 15, at 630.

131. Id. 


\begin{tabular}{|c|c|c|c|c|}
\hline \multicolumn{5}{|c|}{ Comparison of Public Pension and Mutual Fund Investment Advisory Fees } \\
\hline & \multicolumn{2}{|c|}{ Public Pension Funds } & \multicolumn{2}{|c|}{ Mutual Funds } \\
\hline & $\begin{array}{l}\text { Average } \\
\text { Portfolio }\end{array}$ & $\begin{array}{l}\text { Weighted } \\
\text { Average }\end{array}$ & $\begin{array}{l}\text { Average } \\
\text { Fund }\end{array}$ & $\begin{array}{l}\text { Weighted } \\
\text { Average }\end{array}$ \\
\hline Decile & $\begin{array}{l}\text { Size } \\
\text { \$mm }\end{array}$ & $\begin{array}{c}\text { Adv. Fee } \\
\text { (Basis Pts) }\end{array}$ & $\begin{array}{l}\text { Size } \\
\text { Smm }\end{array}$ & $\begin{array}{c}\text { Adv. Fee } \\
\text { (Basis Pts) }\end{array}$ \\
\hline 1 & 36 & 60 & 24 & 77 \\
\hline 2 & 79 & 57 & 47 & 77 \\
\hline 3 & 130 & 49 & 76 & 75 \\
\hline 4 & 194 & 42 & 121 & 74 \\
\hline 5 & 257 & 37 & 185 & 73 \\
\hline 6 & 327 & 42 & 284 & 71 \\
\hline 7 & 437 & 33 & 454 & 73 \\
\hline 8 & 579 & 28 & 759 & 69 \\
\hline 9 & 842 & 22 & 1,527 & 66 \\
\hline 10 & 1,550 & 20 & 9,666 & 50 \\
\hline Overall & 443 & 28 & 1,318 & 56 \\
\hline
\end{tabular}

SOURCE: John P. Freeman \& Stewart L. Brown, Mutual Fund Advisory Fees: The Cost of Conflicts of Interest, 26 J. CORP. L. 609 (2001).

Weighted average management fees on actively managed public pension portfolios were half the fees of comparable mutual funds, in spite of the fact that the average mutual fund portfolio was three times the size of the average institutional portfolio. The relative proportions of large, mid and small cap portfolios were similar. The results are presented graphically in Figure 1:

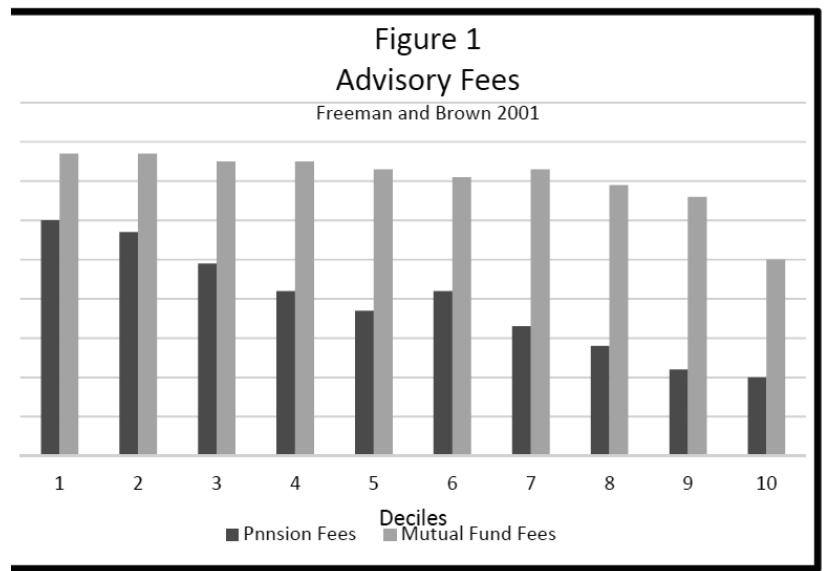


In Figure 1, mutual fund advisory fee rates are relatively flat through the first nine deciles and then dip substantially in the tenth decile corresponding to an average fund size of about $\$ 10$ billion. This is consistent with large funds generating high margins because of economies of scale, which force the manager to institute breakpoints in the contracts so as not to exceed the Schuyt-allowed profit margin ceiling of $77 \%$. Pension fees decline relatively smoothly from the smallest to the largest size deciles. This is consistent with competition forcing fees to decline as asset levels increase. Thus, public sector institutions were able to take advantage of economies of scale where fund investors were not.

The study breaks down fee differences for large, mid and small cap portfolios. It finds the largest differences occur in the large cap sector where weighted average mutual fund fees are fifty-two basis points and pension fees are twenty-one basis points. This is consistent with the Payne and Yerkey results that show average profit margins in the range of 50 to $60 \%$, but higher (70\%) profit margins on managing large cap portfolios. ${ }^{132}$ The study also looked at the advisory fees of the Vanguard Group where all funds are sub-advised. It found that Vanguard fees were in line with comparably sized pension fees.

\section{The Industry Response}

The Freeman-Brown study gained attention in 2003 when scandals of the mutual fund industry came to light. In addition to targeting late trading and market timing, New York Attorney General Elliot Spitzer focused attention on fee issues. The industry was forced to respond. The first response came from the Investment Company Institute. Sean Collins, a senior economist at ICI, based his arguments largely on misdirection. He noted correctly that mutual funds and pension plans have very different organizational structures and operations, serve different clientele and have different business objectives. ${ }^{133}$ He then examined "operating expenses" (management fees plus administrative fees) in detail. He found large differences between mutual funds and pension funds. ${ }^{134}$ This is not surprising and irrelevant to the fundamental issue of comparison of advisory fees of the two types of organizations. Collins did make one notable contribution to the argument. He found that sub-advisor fees on

132. Profitability Benchmarks, supra note 33.

133. Sean Collins, The Expenses of Defined Benefit Pension Plans and Mutual Funds, InV. Co. InST. PERSPECTIVE, Dec. 2003, at 1.

134. Id. at 8 . 
mutual funds are essentially equivalent to pension advisory fees. ${ }^{135}$ This is important and will be useful in Part IV of this Paper.

A second study by Coates and Hubbard was partially funded by the Investment Company Institute. ${ }^{136}$ The principal finding of the paper is that "price competition is in fact a strong force constraining fund advisers." 137 In reaching this conclusion, the paper conducts a detailed analysis of the legal and economic literature and directly criticizes the Wharton study and PPI report as well as the Freeman-Brown findings. ${ }^{138}$ The paper supports its principal conclusions with a core proposition and a regression analysis of fund fees that are demonstrably flawed.

One major problem with the Coates-Hubbard argument is the evidence that many mutual fund investors are uninformed, unsophisticated, and make poor investment decisions. ${ }^{139}$ In addition, frictions associated with the tax code and retirement accounts constrain investors from switching to low fee funds. ${ }^{140}$ Coates-Hubbard argued that given "a sufficient number of buyers engaging in a price search for a given quality of product and service, willing and able to switch to competitors," competitive prices would result. ${ }^{141}$

The problem with the Coates-Hubbard proposition is that with profit margins perhaps as high as $77 \%$, fund sponsors have no incentive to lower fees for all customers in order to retain price sensitive customers. For example, assume there is an actively managed large cap mutual fund with $\$ 10$ billion in assets and a fifty basis point advisory fee. The fund sponsor's profit margin is $70 \%$, the typical large cap profit margin according to Payne and Yerkey. ${ }^{142}$ Given these assumptions, the fund generates $\$ 50$ million in revenues (.005 times $\$ 10$ billion) and operating profits of $\$ 35$ million (.70 times $\$ 50$ million) for the fund sponsor. ${ }^{143}$

Assume the sponsor is confronted with competition from a low-cost fund offering a twenty-five basis point advisory fee. The fund sponsor can keep the whole $\$ 10$ billion in assets but must lower fees across the board so

135. Id. at 2-3.

136. Asher Hawkins, Well-Funded Opinion, Forbes, May 25, 2009, at 28; John P. Freeman, Stewart L. Brown, \& Steven Pomerantz, Mutual Fund Advisory Fees: New Evidence and a Fair Fiduciary Duty Test, 61 OKLA. L. REV. 83, at 107 (2007) (hereinafter "Freeman-Brown-Pomerantz").

137. John C. Coates IV \& R. Glenn Hubbard, Competition in the Mutual Fund Industry: Evidence and Implications for Policy, 33 J. CORP. L. 151, 153 (2007) (hereinafter "CoatesHubbard").

138. Id.

139. Palmiter \& Taha, supra note 40 , at 936.

140. Ayres \& Curtis, supra note 44, at 148-83

141. Coates-Hubbard, supra note 137, at 199.

142. Profitability Benchmarks, supra note 33.

143. Some Analytical Clarity, supra note 30, at 385. 
that revenues fall to $\$ 25$ million and profits fall to $\$ 10$ million. ${ }^{144}$ Or, the fund sponsor can let the funds run off and maintain revenues of fifty basis points on the remaining funds. Assume the competition causes $\$ 1$ billion to exit the fund. By refusing to lower fees across the board, the sponsor continues to earn operating profits of about $70 \%$ of $\$ 45$ million or $\$ 30$ million. ${ }^{145}$ The sponsor's choice is to earn $\$ 10$ million and retain the fee sensitive assets, or $\$ 30$ million, and let the fee sensitive assets leave. ${ }^{146}$ It is not a difficult choice. ${ }^{147}$ Investment advisors with high profit margins will rationally choose to maintain high levels of fees and profits and let feesensitive assets exit the fund. ${ }^{148}$ This reasoning is entirely consistent with the evidence presented in Tables 1,2 and 3 of this Paper. The investment management industry has chosen to maintain active management fees in the face of competition from index funds and has allowed billions of dollars to switch to index funds rather than compete on fees.

The overall Coates-Hubbard conclusions are based heavily on an empirical analysis of fees that is disingenuous and deeply flawed. The Wharton study, PPI report, and 1970 ICA amendments focused on advisory fees independent of administrative fees. Distribution (12b-1) fees did not exist at the time of the legislation. Yet the Coates-Hubbard empirical results that they claim are "direct evidence that mutual fund investors are sensitive to fees," $" 149$ are based on cross-sectional regressions of asset levels on Total Expense Ratios, not advisory fees. This is misleading. Table 2 shows that it is possible for overall fees to decline while advisory fees remain constant. Thus, the Coates-Hubbard regression says nothing about investor sensitivity to advisory fees. The results in Table 2 show that in the face of a doubling of assets between 2005 and 2015, advisory fees actually increased. Coates-Hubbard would struggle to explain that result.

Finally, the Coates-Hubbard assertions violate a basic tenet of economics: in competitive markets price is equal to marginal cost. There is direct evidence that this is not the case for mutual funds. A reasonable approximation of the marginal cost of active portfolio management is the market price of sub-advisory contracts, which include normal profit to the firms providing the services. The Vanguard Group obtains sub-advisory

144. A $70 \%$ profit margin at fifty basis points on $\$ 10$ billion means that costs would be $30 \%$ of $\$ 50$ million or $\$ 15$ million. If it is assumed that all of these costs are fixed, then the dollar profit would be revenue of $\$ 25$ million less costs of $\$ 15$ million or $\$ 10$ million.

145. Using the same logic, if all costs are fixed, then the $\$ 45$ million in revenue, less $\$ 15$ million in costs, yields $\$ 30$ million in profit. In all likelihood, costs are not precisely constant, but the main point of the illustration is clear.

146. Some Analytical Clarity, supra note 30, at 386.

147. Id.

148. Id.

149. Coates-Hubbard, supra note 137, at 215. 
services at roughly one fourth of the average advisory fees charged by the other nine large fund families in Panel A of Table 3. It is interesting that the average profit margin (Revenue - Cost)/Revenue of the other nine fund families in Panel A of Table 3 is $76 \%$ under the assumption that the true cost of investment management services is the average cost of the Vanguard funds. It is no accident that this is close to the Fiduciary Standard Maximum profit margin codified in the Schuyt case. The advisory function is subject to economies of scale and the nine largest fund families operate relatively very large mutual funds. It is to be expected that large funds generate high profit margins.

\section{The U.S. Supreme Court Weighs in: Jones v. Harris Assocs., L.P.}

In Jones,${ }^{150}$ an excessive fee case filed under ICA $\S 36(\mathrm{~b})$, Harris Associates charged the Oakmark Fund greater advisory fees than it charged institutional clients for similar services. The District Court ignored the institutional fee comparison and gave great weight to the comparison of the Oakmark Fund advisory fees to advisory fees charged by similar mutual funds and granted summary judgment for the defendants. Plaintiffs appealed to the Seventh Circuit. The three-judge panel, in a ruling by Judge Easterbrook, cited Coates-Hubbard and argued that the Gartenberg standard was obsolete because competition imposed discipline on advisory fees. The full court denied rehearing, but five judges, led by Judge Posner, dissented, citing Freeman-Brown, ${ }^{151}$ Birdthistle,${ }^{152}$ and a working paper by Kuhnen ${ }^{153}$ finding that cronyism between agents in the mutual fund industry led to increased fees that were borne by shareholders. ${ }^{154}$ The Supreme Court accepted the case for review to resolve a split among the Circuit Courts of Appeal as to the proper standard under \$36(b) for determining if a breach of fiduciary duty had occurred and unanimously reaffirmed Gartenberg, despite its lack of "sharp analytical clarity." The court concluded that Gartenberg accurately reflected "the compromise that is embodied in §36(b)," and that it had provided "a workable standard for nearly three decades. The debate ... regarding today's mutual fund market is a matter for Congress, not the courts." 155

The "workable standard for nearly three decades" is highly favorable to the investment management industry and punitive to investors, but the court was surely aware of that and that the standard is consistent with

150. 559 U.S. 335, 130 S. Ct. 1418 (2010).

151. Freeman-Brown, supra note 15.

152. Birdthistle, supra note 97.

153. Kuhnen, supra note 95.

154. Jones, 559 U.S. at 335.

155. Id. at 353 (Thomas, J., concurring). 
Congressional intent as stated in the Senate Report. The court made perfectly clear that changes in the status quo depended on "Congress, not the courts."

It follows that the essentially flat advisory fees from 2005 to 2015 , and indeed from 1960 to 2015, are an artifact of the unique corporate structure of mutual funds. The investment management industry has successfully manipulated the political and judicial system to insulate itself from competitive pressures and maintain above market advisory fee rates. The economic impact is examined in Part IV. First, we examine recent court cases involving sub-advisory fees in which the industry has so far prevailed.

\section{E. Sub-Advisory Fee Cases}

A substantial number of mutual funds (and variable annuities) are subadvised by money managers unaffiliated with the fund sponsor. Subadvisory fee rates are typically a fraction of the rates charged to the funds' investors. Fund sponsors justify the mark-up as compensation for "monitoring costs." Plaintiffs charge that fees are excessive since subadvisory fees are determined by arm's length bargaining and "monitoring costs" are minimal.

Currently, several sub-advisory cases are working their way through the judicial system. Preliminary results are unpromising for plaintiffs. After a trial, one district court in New Jersey found for the defendants and dismissed the plaintiff's lawsuit. ${ }^{156}$ Similarly, in Kasilag v. Hartford Investment Financial Services, LLC (Kasilag), the same district court (but a different judge) granted defendants motion to dismiss, finding that plaintiffs had "elected to present minimal evidence with regard to comparative fee structures, fall out benefits, or economies of scale." ${ }^{157}$ One promising aspect of Kasilag is that the court gave some "limited weight" to the Vanguard comparison because the fund in question used the same subadvisor as a similar Vanguard fund. ${ }^{158}$ Both cases are on appeal and there are several other similar cases in various stages, none of which have yet been dismissed.

One common element of these cases is that the courts place great reliance on fund independent directors and the business judgment rule. Recall that the ICA put independent directors in the role of "watchdogs" for fund investors' interests, especially as regards to fees. A casual perusal of the Fund Director's Guidebook reveals no material on the exercise of

156. Sivolella v. AXA, 2016 WL 4487857 (D.N.J. 2016).

157. No. 11-1083, 2017 WL 773880 (D.N.J. Feb. 28, 2017), at*71 (D.N.J. 2017).

158. Kasilag v. Hartford Inv. Fin. Serv., LLC, 2012 WL 6568409, at *4-5 (D.N.J. 2012). 
business judgment on overall fund policy but detailed coverage of responsibilities regarding advisory fees. Fund directors are made aware of the legal implications of their roles and the comparison of advisory fees to fees determined by arm's length bargaining.

It would seem as though independent directors chosen for their business acumen would recognize that the sub-advisory fees they approve are negotiated at arm's length. It should follow that truly independent directors would rebel at the fund sponsor marking up such fees by 100 to $200 \%$ in the form of advisory fees. Directors focused on fund investor interests would not allow that to happen. Yet, there is no indication that this has ever occurred.

So, in addition to somnolence and the Palmiter assertion that fund directors are "feckless" and "weak," ${ }^{159}$ we can add the adjectives incompetent and toothless. Moreover, these observations call into question the business judgment rule itself. Independent directors have demonstrably failed in their role as watchdogs. Further, by continuing to rely on the business judgment rule, the judicial system avoids confronting the inconvenient fact that advisory fees on sub-advised funds are much higher than fees subject to the forces of arm's length bargaining.

\section{THE ECONOMIC CONSEQUENCES OF EXCESSIVE ADVISORY FEES}

The investment management industry has been extraordinarily successful in manipulating the political and judicial systems to maintain high investment advisory fees. This has resulted in excess payments of billions of dollars annually by investors and has resulted, moreover, in excess returns to the owners of investment management firms.

In this Section, we estimate annual excess fees paid relative to fees that would be generated in a competitive market. Finally, we estimate the excess returns that have accrued to the owners of the universe of publicly traded investment advisory firms specializing in mutual funds and test these returns for statistical significance.

\section{A. Estimating Annual Excess Advisory Fees}

\section{Estimates Using the Freeman-Brown Results}

Freeman and Brown compared advisory fees charged public pension funds to mutual fund advisory fees and found that the latter were twenty-

159. Palmiter, supra note 91 , at 165. 
eight basis points higher. ${ }^{160}$ This difference, when applied to the current level of mutual fund assets, provides an estimate of the annual overcharging of mutual fund clients relative to fees determined by arm's length bargaining. The data are somewhat stale but provide a reasonable approximation of excess fees.

In 2015 , total actively managed open-end mutual fund assets, exclusive of money market funds, were $\$ 9.5$ trillion. The product of $\$ 9.5$ trillion times twenty-eight basis points yields a first approximation of annual overcharging of about $\$ 26.6$ billion. This estimate is understated because of the size differential between the pension and mutual fund portfolios. Pension fees would be lower on larger portfolios.

Freeman and Brown provide a means to estimate pension fees on larger portfolios. They present the results of a regression of pension fees on the log of pension assets. ${ }^{161}$ Applying the results of that regression to the log of the average mutual fund portfolio asset level in their paper yields an estimate of 21.1 basis points. The difference between 21.1 basis points and the average mutual fund advisory fee of fifty-six basis points yields an estimate of overcharging of 34.9 basis points. Applying 34.9 basis points to the 2015 level of actively managed mutual fund assets suggests an annual overcharging of about $\$ 33.2$ billion.

This number could be too high. Freeman and Brown only looked at equity portfolios ${ }^{162}$ and it is generally known that fees are lower on fixed income funds. However, there is evidence that profit margins on fixed income portfolios for fund sponsors are comparable to equity portfolios. For instance, in periods of normal interest rates, the margins on money funds are comparable to large cap portfolios and high yield bond portfolios have profit margins similar to mid and small cap portfolios. ${ }^{163}$

Mutual fund and pension advisory fees are not strictly comparable because there are some small cost differences. The Wharton study and PPI report both reported that it was more expensive to manage pension portfolios because custodial and marketing fees are typically covered by pension fees but covered under separate contracts for mutual funds. However, there are certain costs that must be covered when managing mutual fund portfolios that are not present when managing institutional portfolios. These include director's fees and, because mutual funds are marked to market daily, fund accounting costs. Using Lipper Analytical data, Freeman, Brown and Pomerantz estimate that it costs not more than

160. Freeman-Brown, supra note 15, at 631.

161. Id. at 635 .

162. Id. at 639 .

163. Profitability Benchmarks, supra note 33. 
about three basis points more to manage mutual funds ${ }^{164}$ and these estimates ignore the marketing and custodial costs suggested by the Wharton study and PPI Report. In all likelihood, the cost differences are a wash.

Coates-Hubbard also argued that it is more expensive to manage mutual fund portfolios because large and frequent inflows and redemptions occur for mutual funds that do not happen with pension portfolios. ${ }^{165}$ However, mutual fund portfolio managers hold cash positions to act as shock absorbers, and fund investors, not the fund manager, absorb these and the trading costs associated with inflows and redemptions. At any rate, managing cash flows is a normal function of portfolio management in pension as well as mutual fund portfolios. Moreover, these differences are not present for sub-advised portfolios that yield similar estimates and are examined in the next sections.

\section{Vanguard Fees}

All of the Vanguard Group's actively managed mutual funds are subadvised, and the fees are aggressively negotiated at arm's length.

Moreover, the investment management firms that manage these portfolios earn normal profits or they would not agree to provide the services.

Vanguard is a mutual organization and provides its services at cost, so it is valid to compare the weighted average advisory fees charged by the Vanguard Group to fees charged to mutual funds in general and to use these differences to estimate the annual amount that mutual funds clients are overcharged for advisory fees.

Numbers in Panel A of Table 3 allow for the calculation of annual excess advisory fees using the weighted average Vanguard advisory fee as a proxy for the advisory fees determined by arm's length bargaining. The weighted average annual advisory fee for the ten largest mutual fund families was forty basis points including the 10.7 basis points Vanguard advisory fees. Excluding Vanguard assets from the calculation yields a weighted average annual advisory fee for the remaining nine large fund families of forty-five basis points. It follows that on average the top nine fund families are overcharging their clients about 34.3 basis points (45 minus 10.7) on an annual basis. Applying the 34.3 basis point estimate to the total of non-Vanguard actively managed open-end fund assets of $\$ 8.86$ trillion yields an estimate of $\$ 30.4$ billion annually. ${ }^{166}$ This is not

164. Freeman-Brown-Pomerantz, supra note 136, at 109 n. 90 (2007).

165. Coates \& Hubbard, supra note 137, at 185 (2007).

166. This is likely to be a very conservative number. From Table 2, total active assets are $\$ 9.5$ trillion with a weighted average advisory fee of 53.2 basis points. The weighted average advisory fee of the top ten fund families in Panel A of Table 3 is 40.1 basis points, which 
materially different from the $\$ 33.2$ billion estimate using the FreemanBrown numbers. The Vanguard numbers are immune from the criticisms of Freeman-Brown because sub-advised portfolios are subject to the same cash management constraints and costs as portfolios that are not subadvised.

The $\$ 30.4$ billion estimate of annual overcharging ignores possible overcharging on money fund and indexed portfolios and thus is likely conservative. On the other hand, the estimate could be somewhat high because the Vanguard funds are much larger than normal and thus the subadvisory fees would be lower than average fees because of economies of scale and aggressive breakpoints negotiated by Vanguard.

Next, we estimate annual overcharging using the universe of subadvised mutual funds excluding Vanguard. This allows for a more granular and accurate procedure to estimate the annual overcharging of advisory fees.

implies that the weighted average fees on the $\$ 4.9$ trillion of assets outside the top ten families was approximately sixty-five basis points and the difference between sixty-five basis points and the Vanguard average 10.7 basis points is 54.3 basis points. Multiplying 54.3 basis points times the $\$ 4.9$ trillion of assets outside the top ten families is about $\$ 26.4$ billion. Overcharging on the nine largest fund families would be about $\$ 13.8$ billion ( 34.3 basis points times $\$ 4$ trillion) and yields an estimate of total annual overcharging of about $\$ 40$ billion. 
3. Non-Vanguard Sub-Advised Funds
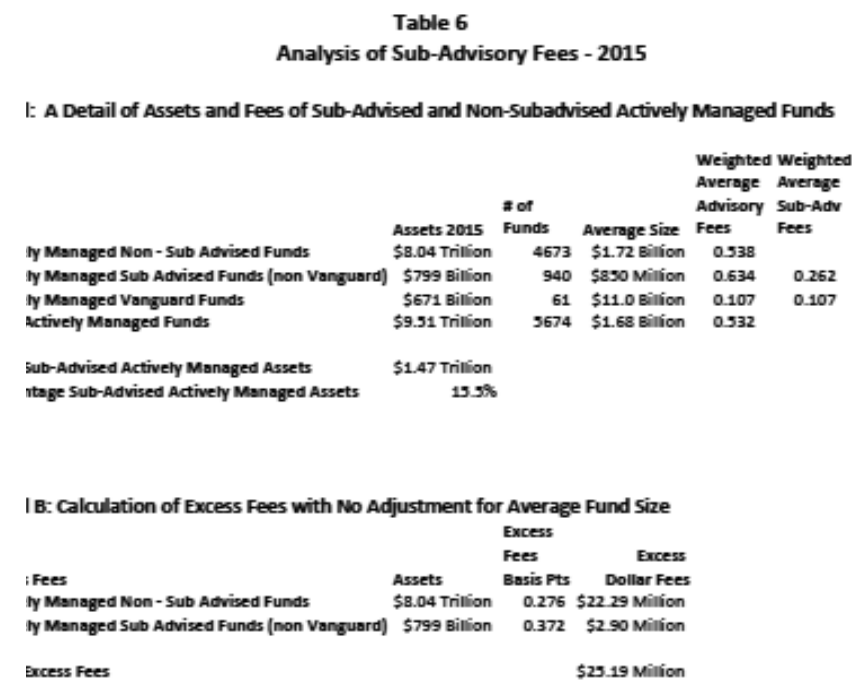

IC: Calculation of Excess Fees with Adjustment for Average Fund Size

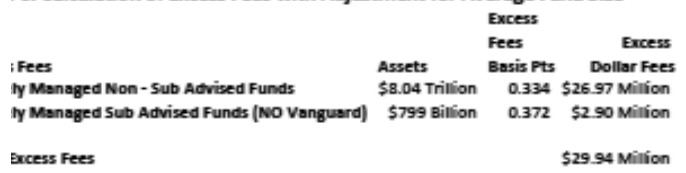

A significant proportion of actively managed mutual fund assets are sub-advised. Details are provided in Panel A of Table 6. Of the $\$ 9.5$ trillion of actively managed funds at the end of $2015,15.5 \%$ were subadvised: $\$ 671$ billion in Vanguard funds and $\$ 799$ billion in other fund families. ${ }^{167}$ On average, the sub-advised funds were smaller than the nonsub-advised funds, $\$ 850$ million versus $\$ 1.72$ billion, and advisory fees were larger, 63.4 basis points versus 53.8 basis points.

167. There are also about $\$ 1.3$ trillion in assets in "Funds of Funds" that are technically sub-advised and that we ignore in our analysis because the reporting is not standardized. In most cases, though, the assets in these funds are reflected in the assets held by the underlying funds themselves, and the fees charged are attributed at that level as well. In some cases, the fund of funds charges an overlay fee of some nominal value. This fee is not studied as part of this analysis. 
The weighted average sub-advisory fees on the non-Vanguard subadvised funds was calculated at 26.2 basis points. This is a reasonable estimate of market determined/arm's length negotiated fees on funds with an average size of about $\$ 850$ million. In turn, these fees can be compared to actual advisory fees to estimate the level of excess fees paid annually by mutual fund investors. These calculations are shown in Panel B of Table 6.

Excess fees are the sum of excess fees on \$8.04 trillion of non-subadvised and $\$ 799$ billion of sub-advised funds. The difference between the average advisory fee on the $\$ 8$ trillion of non-sub-advised assets and 26.2 basis points is 27.6 basis points. This excess applied to the $\$ 8$ trillion of assets yields annual excess fees of $\$ 22.3$ million. This is a conservative estimate because the average non-sub-advised fund has twice the level of assets of the sub-advised fund. The difference between the weighted average advisory fees on the sub-advised funds (63.4 basis points) and the weighted average sub-advisory fees of 26.2 basis points is 37.2 basis points. This is an estimate of the percentage overcharging on sub-advised funds. Applying this number to the $\$ 799$ billion of sub-advised assets yields an annual overcharging of $\$ 2.9$ million. Thus, total excess fees are estimated to be about $\$ 25.2$ million. This number likely underestimates the true number because the average sub-advisory fee was estimated using funds with average assets of about $\$ 850$ million. However, the average non-sub-advised fund had about $\$ 1.72$ billion in assets (from Panel A).

We adjusted our estimate of excess fees in Panel B by estimating the average sub-advisory fee to be paid if the average fund's size were $\$ 1.75$ billion. We regressed the log of sub-advisory fees on the log of subadvised assets and extrapolated the results. Using this procedure, we estimated that the average sub-advisory fee on a $\$ 1.75$ billion portfolio would be 20.4 basis points.

We present the results of this analysis in Panel C of Table 6. The difference between 20.4 and 53.8 basis points is 33.4 basis points, which is an estimate of the average overcharging on $\$ 8$ trillion of non-sub-advised funds with an average size of $\$ 1.75$ billion. Using this difference yields an estimate of overcharging of about $\$ 27$ million on non-sub-advised funds and a total of about $\$ 29.9$ million annually.

Using various procedures, we have estimated that mutual fund investors are overcharged between about \$25 and \$33 million per year. These estimates are conservative because they ignore overcharging on money and index funds. We conclude that a rough estimate of overcharging is about $\$ 30$ million per year. 


\section{B. Excess Returns to Fund Sponsors}

Economic theory suggests that in competitive markets long run prices will tend to equal marginal costs and producers will earn normal profits and normal rates of return for owners. Absent significant competitive forces, producers can maintain prices above marginal costs and earn economic profits and excess returns for owners. In this paper, we show prices well above marginal costs in the mutual fund industry. Over long periods, advisory fees are consistently above fees known to be determined by arm's length bargaining. Moreover, these excess fees are the result of the influence of the investment management industry on the political/judicial/regulatory system. If this view is correct and fund sponsors do indeed charge excess fees, then the results should show up in the forms of excess returns to the shareholders of the investment management firms that sponsor and operate mutual funds.

Most investment management firms are either privately held (Fidelity, American Funds) or subsidiaries of large banks or insurance companies (Pimco, JP Morgan). Here, we identify the universe of publicly traded investment management firms whose principal line of business is sponsoring and managing mutual funds. Fund sponsors currently trading ${ }^{168}$ are identified by matching firms in the SNL Financial Index of Money Managers with the Morningstar Direct database. These are listed in Panel A of Table 7. This list is subject to survivorship bias. Over the years, many fund sponsors have been absorbed into larger institutions. We have made a good faith effort to identify these firms by examining the composition of SIC Code 6282 (Investment Advice) over time. These firms are listed in Panel B of Table 7.

168. Data is as of December 31, 2016. 


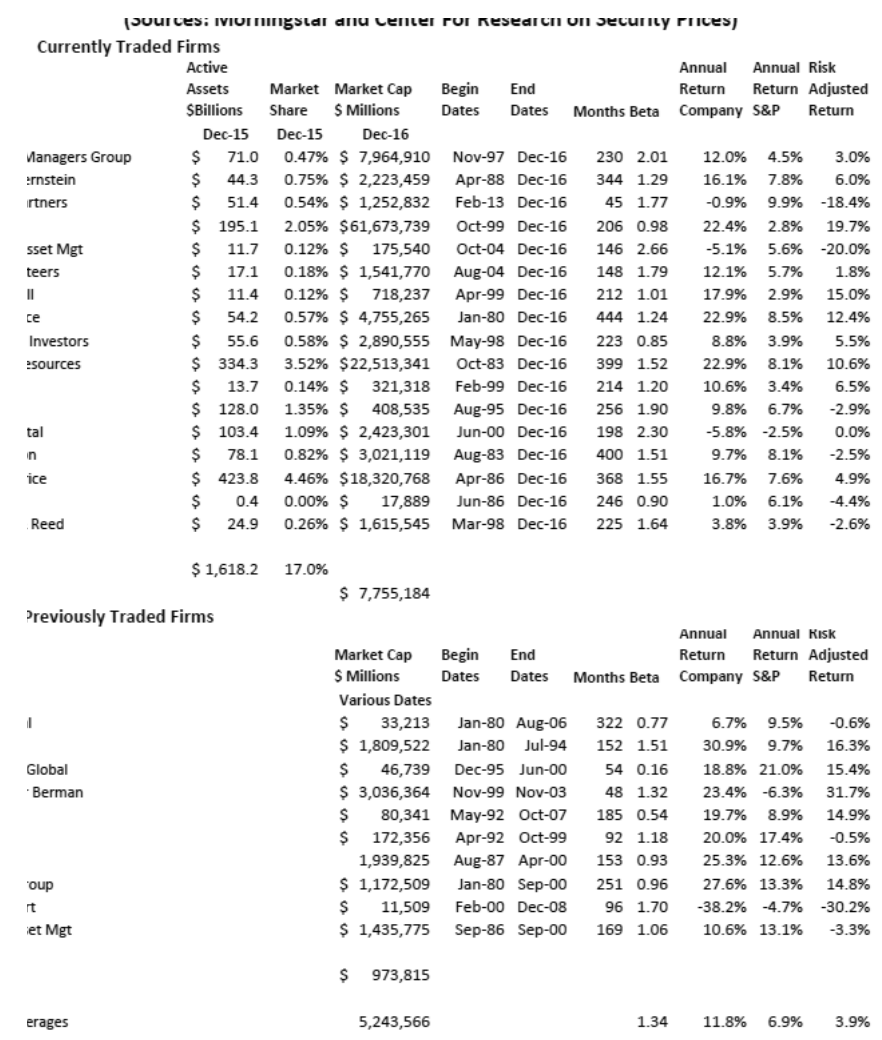

We examine the thirty-seven-year period from 1980 to 2016. The beginning of this period corresponds roughly to the period when courts began to apply the business judgment rule and Gartenberg standard. The Center for Research on Security Prices database of monthly returns is the principal source of data for Table 7. We use Morningstar Direct to show Active Assets under management for currently traded firms.

Panel A identifies seventeen currently traded fund sponsors and Panel $B$ lists ten fund sponsors that traded in the past. All of these firms were absorbed into larger firms.

The first two numerical columns of Panel A show Active Assets under management and market share of the currently traded firms as of December 2015. Collectively, these firms manage about $\$ 1.6$ trillion in active assets and about $17 \%$ of total active assets.

The third numerical column of Table 7 shows the market capitalization of the fund sponsors. It is presented as of December 2016 for currently traded firms and as of the last month the firm appears in the CRSP database for Panel B firms. In general, the fund sponsors are small 
capitalization stocks. Average market cap in Panel A is $\$ 7.8$ billion and $\$ 974$ million in Panel B. Overall average market cap is $\$ 5.3$ billion. However, three currently traded firms qualify as large capitalization stocks: Blackrock, Franklin Resources, and T. Rowe Price.

The remaining columns of Table 7 detail the annualized returns of fund sponsors and the S\&P 500 index returns over corresponding periods. We estimate annual risk adjusted returns for each company by subtracting the product of its market model beta and the returns on the S\&P 500 from sponsor returns over the corresponding period. The average market model beta coefficient was 1.34, an indication that returns of these firms are highly sensitive returns to the market. Overall, average risk adjusted returns were $3.9 \%$ annually.

There are indications that scale economies impact excess returns. Ranking the seventeen firms in Panel A by assets under management as of the end of 2015 and splitting the sample reveals that the average risk adjusted excess returns on the eight largest market share firms was $4.8 \%$ and $-0.4 \%$ of the nine smallest firms. Similarly, risk adjusted returns are associated with market capitalization. Ranking all twenty-seven firms by market cap reveals that the thirteen largest firms earned $9.1 \%$ risk adjusted returns, while the fourteen smallest firms earned a risk adjusted $-0.9 \%$. The overall insight from Table 7 is that, consistent with the economic profit hypothesis, the universe of publicly traded mutual fund sponsors earns high risk adjusted rates of return for their owners over long time periods.

To test for statistical significance, we construct a capitalization weighted index of total returns for the thirty-seven year period from 1980 to 2016. The monthly returns for each of the firms in Table 7 are included in the index for the times they were traded, and the returns included in the CRSP database. Numerical results of this analysis are presented in Table 8 and graphical results in Figure 2.

\begin{tabular}{|c|c|c|c|}
\hline \multicolumn{4}{|c|}{ Analysis of Fund Sponsor Returns versus the S\&P 500 Index 1980-2016 } \\
\hline \multirow{2}{*}{\multicolumn{4}{|c|}{ I A Returns }} \\
\hline & & Standard & \\
\hline & Compound & Deviation & \\
\hline & Annual & of & Compound \\
\hline & Return & Returns & Value of $\$ 1$ \\
\hline Cap Weighted Index & $18.7 \%$ & $26.4 \%$ & $\$ 563.59$ \\
\hline S\&P 500 Index & $8.5 \%$ & $15.0 \%$ & $\$ 20.74$ \\
\hline \multicolumn{4}{|c|}{ I B CAPM Test of Excess Returns versus the S\&P 500} \\
\hline Cap Weighted Index & alpha & beta & Rsq \\
\hline & 0.0079 & 1.39 & 0.61 \\
\hline Std Error & 0.00224 & 0.052 & \\
\hline$t$ & 3.51 & 26.9 & \\
\hline
\end{tabular}


From Panel A of Table 8: overall, the compound average annual return to the owners of the firms sponsoring mutual funds was $18.7 \%$ versus $8.5 \%$ on the S\&P 500. An investment of $\$ 1$ in the S\&P 500 in 1980 would have grown to $\$ 20.74$ by 2016 while an investment in the cap weighted index of fund sponsors would have grown to $\$ 563.59$. The index of fund sponsor returns was more volatile than the S\&P 500. The annual standard deviation of return on the cap weighed index was $26.4 \%$ versus $15 \%$ for the S\&P $500 .{ }^{169}$

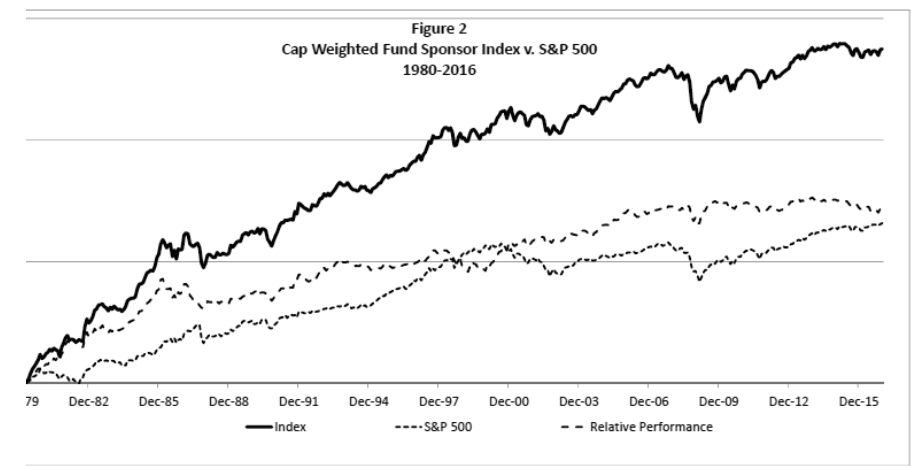

Results are presented graphically in Figure 2, which plots the indexes on a $\log$ scale. The top line is the investment value of $\$ 1$ from 1980 in the Cap Weighted Index and the bottom dashed line is the S\&P 500 index. The middle-dashed line is the growth of the cap weighed index relative to the S\&P 500. An increase in the dashed line represents periods of outperformance and declining sections represent periods of underperformance.

The outperformance of the cap weighted index is relatively consistent throughout the thirty-seven year period but appears to diminish somewhat in later periods. Relative performance is flat around the 1987 and 2008 market crash periods and it appears as though the fund sponsor index has not outperformed since that period.

In Panel B of Table 8 we show the results of a test of the statistical significance of excess returns of the fund sponsor index. We use the single factor CAPM as the asset pricing model. The capitalization weighted index of fund sponsors exhibits statistically significant excess returns at the 0.01 level. The alpha is $0.8 \%$ per month, an indication of annualized excess returns of about $9.5 \%$.

169. This is not an especially high level of volatility for a sector specific index. For instance, the annualized standard deviation of the XLF financial sector spider from inception in 1999 forward was an identical 26.3 percent. 
The statistical tests confirm the intuition of Table 7. Investment management firms that sponsor mutual funds have earned very high risk adjusted returns for their owners over long time periods. The most probable cause of these excess returns is the captive nature of mutual funds vis-à-vis the investment management firms that sponsor and operate them and the resultant lack of arm's length bargaining of advisory fees.

Finally, on a lighter note, Paul Samuelson, a Nobel Laureate, offered some useful insights in testimony before Congress in 1967:

I decided that there was only one place to make money in the mutual fund business - as there is only one place for a temperate man to be in a saloon, behind the bar and not in front of the bar. And I invested in ... [a] management company." 170

Samuelson was way ahead of his time.

\section{CONCLUSION}

Mutual funds are unique corporate organizations. They have no employees or physical assets. Essentially, a mutual fund is a collection of contracts with various service providers. The principal service provider is the investment management firm that creates, brands and manages the fund. Sitting atop the fund is a part time board constrained in its ability to act on behalf of fund shareholders. Essentially, fund sponsors are in a monopoly position vis- à-vis the funds they operate.

Mutual fund "markets" seem to correspond closely to the model of perfect competition. The evidence on fund fees presented here is thus counterintuitive. However, the evidence is also compelling. The investment management industry has successfully manipulated the political, regulatory, judicial system and has maintained advisory fees above market rates for more than fifty years.

This Paper consists of two intertwined analyses: financial and legal. Financially, fund advisory fees have been essentially constant since at least the 1960s in spite of high growth rates in mutual fund assets. Advisory fees currently exceed fees established by arm's length negotiation by about $\$ 30$ billion annually. The universe of publicly traded mutual fund sponsors has earned statistically significant excess returns for shareholders over a thirty-seven year period.

Legally, the Wharton study and PPI report identified the fundamental conflict of interest that fund sponsors have been able to exploit vis-à-vis the funds managed. Both the study and report showed significant differences between fund advisory fees and fees determined by arm's length bargaining

170. Mutual Fund Legislation of 1967: Hearings on S. 1659 Before the S. Comm. on Banking \& Currency, 90th Cong. 358 (1967) (statement of Paul Samuelson). 
and led to the 1970 ICA amendments that made fund sponsors fiduciaries with respect to fund fees. This proposed "solution" had a certain face validity. However, the Senate Report signaled the clear intent of Congress to maintain the status quo where fund fees are concerned.

The judicial system dutifully established legal precedent consistent with the legislative intent of Congress, aided in this endeavor by the investment management industry, which astutely chose to settle cases in which the outcome might be an unfavorable precedent. In Burks, the courts determined that the business judgment rule was applicable to mutual fund governance even though all important business decisions impacting the fund are made by the fund sponsor. ${ }^{171}$ In Gartenberg, the industry brought to trial a fund with anomalous processing costs that enabled the courts to disallow fee comparisons with fees determined at arm's length. ${ }^{172}$

Gartenberg also put in place a highly subjective and restrictive fiduciary standard for plaintiffs in fee cases to overcome. The business judgment rule and subjective fiduciary standard were on full display in Schuyt where the court determined that a $77 \%$ profit margin was not excessive. ${ }^{173}$ In Kalish, the fund at issue conflated advisory and administrative fees and set the precedent of disallowing comparison of fees on Vanguard Funds where all funds are sub-advised. ${ }^{174}$

It would be simplistic to fault the judicial system for treating mutual fund investors unfairly. The system enforces laws and the legislative intent underpinning those laws, period. In a sense, the judicial system is agnostic about justice and fairness, which are philosophical concepts and subjective in nature.

Public Choice Theory offers some useful perspective. Mancur Olson, in his book "The Logic of Collective Action" posited that some groups have a larger impact on government policies than others. ${ }^{175}$ In a democratic system, people with common interests will generally band together to achieve common goals. However, if the benefits of a political outcome are concentrated in the hands of a few and the costs are diffused among many, the beneficiaries are motivated to influence the political process in their favor. At the same time, those who bear the costs have little incentive to organize to protect their interests.

The mutual fund industry offers a prime illustration of Olson's insights. It is estimated here that the investment management industry overcharges investors by about $\$ 30$ billion annually in the form of excess

171. Burks v. Lasker, 441 U.S. 471, 471 (1979).

172. Gartenberg v.Merill Lynch Asset Mgmt., 694 F.2d 923, 931 (2d Cir. 1982).

173. Schuyt Rowe Price Prime Res. Fund, 663 F.Supp 962,989 n. 77 (S.D.N.Y. 1987).

174. Kalish v. Franklin Advisers Inc., 742 F. Supp. 1222, 1222 (S.D.N.Y. 1990).

175. Mancur Olson, The Logic of Collective Action 127-28 (1965). 
advisory fees. The $\$ 30$ billion is spread among ninety million investors so that on average each investor pays about $\$ 300$ per year in excess fees. Yet the nine largest investment management firms in Table 3 who collectively manage about $\$ 4$ trillion in active assets would each benefit by about $\$ 1.5$ billion per year, on average. Certainly, the motivation exists for the fund sponsors to tilt the playing field in their favor.

Investment management industry power and influence were not limited to the 1970 Amendment to the ICA and subsequent case law. Brown (2017) explores the regulatory capture of the SEC and the concomitant deference of the Commission to industry interests.

The late trading and market timing scandals of 2003 led to the Mutual Fund Reform Act of 2004 that the industry successfully aborted. ${ }^{176}$ The comments of the architect of that bill, Senator Peter Fitzgerald, are especially cogent: "The mutual fund industry is now the world's largest skimming operation - a $\$ 7$ trillion trough from which fund managers, brokers and other insiders are steadily siphoning off an excessive slice of the Nation's household, college, and retirement savings."177 Since Senator Fitzgerald made his comments, mutual fund assets have more than doubled and fund sponsors continue to profit handsomely from the situation, with no effective regulation by Congress, the SEC, or the courts.

176. See Regulatory Capture, supra note 13 (describing how the investment management industry has effectively captured the SEC).

177. Mutual Funds: Trading Practices and Abuses that Harm Investors: Hearing Before the Fin. Mgmt., The Budget, \& Int'l Sec. Subcomms. of the S. Comm.on Governmental Affairs, 108th Cong. 3 (2003) (statement of Senator Peter G. Fitzgerald). 